\title{
Comparison of the efficiencies of two TR-FRET methods to detect in vitro natural and synthesized inhibitors of the Raf/MEK/ERK signaling pathway
}

\author{
This article was published in the following Dove Press journal: \\ International Journal of High Throughput Screening \\ 29 May 2010 \\ Number of times this article has been viewed
}

\author{
Fabienne Saab ${ }^{1,2}$ \\ Sylvain Routier ${ }^{2}$ \\ Jean-Yves Mérour ${ }^{2}$ \\ Valérie Bénéteau ${ }^{2}$ \\ Françoise Schoentgen ${ }^{1,3}$ \\ 'Centre de Biophysique Moléculaire \\ UPR430I CNRS, affiliated to Orleans \\ University and to INSERM, France; \\ ${ }^{2}$ Institut de Chimie Organique \\ et Analytique UMR6005 CNRS, \\ Université d'Orléans, France; 'IMPMC \\ UMR 7590 CNRS, Université Pierre et \\ Marie Curie, France
}

Correspondence: Françoise Schoentgen IMPMC UMR 7590 CNRS, Université Pierre et Marie Curie-Paris 6, Campus Boucicaut, 140 rue de Lourmel, 75015 Paris, France

Tel +33 (0) | 44277247

Fax +33 (0)। 44273785

Email francoise.schoentgen@impmc. jussieu.fr

\begin{abstract}
Numerous types of cancer operate through the deregulation of the Raf/MEK/ERK pathway. It is therefore of importance to design and synthesize inhibitors of this pathway. Consequently, we have developed several tests to measure in vitro the effect of inhibitors on the activity of the complete cascade Raf-1/MEK/ERK and also on the activities of Raf-1, MEK, and ERK individually. We present here the results obtained with two time-resolved fluorescence resonance energy transfer (TR-FRET) methods by comparison with a classical radioactivity method and experimental data found in literature. The capability of a series of optimized assays to detect different types of inhibitors is evaluated and discussed.
\end{abstract}

Keywords: Raf/MEK/ERK cascade, inhibitors of Raf-1, MEK, and ERK, PEBP/RKIP, phosphocellulose filter binding assay, time-resolved fluorescence resonance energy transfer

\section{Introduction}

Protein kinases implicated in the Raf/MEK/ERK pathway are important targets for cancer therapeutics ${ }^{1-4}$ because they are implicated in $30 \%$ of all cancers. This pivotal pathway, present in all eukaryotic cells, relays growth factor signals from the cell surface to the nucleus via a cascade of specific phosphorylation events involving the proteins Ras, Raf-1, MEK, and ERK (Figure 1) to regulate fundamental cellular processes, including proliferation, differentiation, and cell survival. ${ }^{5}$ Constitutive upregulation of wild-type Raf- 1 activity is a common feature of solid tumors and can arise by several mechanisms. Among the main mechanisms leading to activation of the Raf- 1 pathway, oncogenic mutations within upstream Ras gene ${ }^{6,7}$ was observed in pancreatic $(90 \%)$, thyroid (50\%), colorectal (50\%), non small cell lung carcinoma (NSCLC, 35\%), hepatocellular carcinoma (HCC, 30\%), acute myeloid leukemia (AML, 30\%), melanoma $(15 \%)$, and kidney tumors $(10 \%)$. Constitutive Raf- 1 activation can also be driven by oncogenic mutations or overexpression of upstream receptor tyrosine kinases (RTKs) in particular the epidermal growth factor receptor (EGFR). ${ }^{8}$ The upregulation of the Raf-1 pathway in numerous cancers indicated that inhibition of Raf- 1 is a promising strategy in cancer therapy. ${ }^{9,10}$ Thus, over the past 10 years, several small-molecule kinase inhibitors were synthesized and, at present, seven Raf-1 kinase inhibitors have been evaluated preclinically or clinically. These new compounds include: sorafenib, PLX4032, ZM336372, AZ628, Raf265, AAL881, and LBT613. ${ }^{9,11}$ Other therapeutics agents have been developed that act on upstream and downstream points of Raf in 
hormones, chemokines,

interleukines,
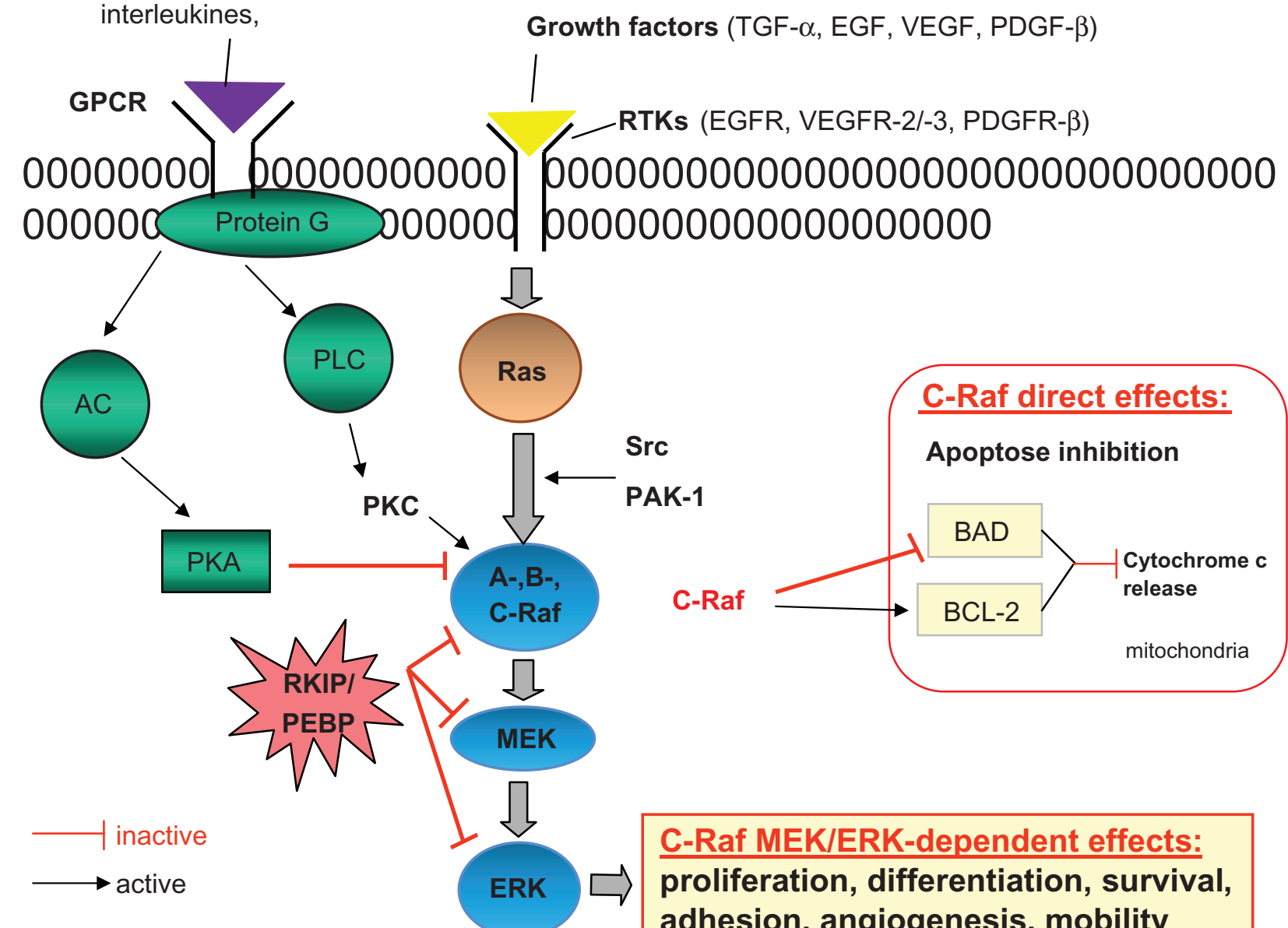

C-Raf MEK/ERK-dependent effects: proliferation, differentiation, survival, adhesion, angiogenesis, mobility

Figure I The Raf/MEK/ERK pathway. The role of the pathway in cells is indicated as well as the main modulators that activate or inhibit the pathway.

the EGFR/Ras/Raf/MEK/ERK signaling pathway. MEK is a particularly promising target that has received much attention in recent years. To date, several MEK kinase inhibitors have advanced to phase II clinical trials, among them are included CI-1040, AZD-6244/ARRY-142886, and PD-0325901. ${ }^{12-15}$

At present, in order to reduce any side effects in future therapeutic treatment, clinicians are looking for products that could be associated in multitherapy treatments. The latter could be adapted individually to each patient and the therapeutics could take into account the particular signal pathways and metabolism of the individual patients. Considering the need for new inhibitors able to target either Raf-1 or other enzymes of the Raf/MEK/ERK cascade, we developed assays adapted for high throughput screening to test these new compounds rapidly and easily. Numerous technologies can be used to measure protein kinases activity in vitro. These techniques include scintillation proximity assay (SPA), time-resolved fluorescence resonance energy transfer (TR-FRET), and fluorescent polarization (FP). There are a number of detailed reviews of these commonly employed technologies. ${ }^{16,17}$ While considering the regular development of new technologies, assay developers or users must take into account several factors prior to designing experiments. For example, which assay technology should be used? What are the advantages and disadvantages of a cascade assay compared with a direct assay format? The advantages and drawbacks of these assays should be analyzed relative to their impact on the search for specific inhibitors.

Our goal in this study is to rapidly characterize new inhibitors of the Raf/MEK/ERK cascade while considering their possible mode of action, ie, 1) inhibitors specific for one of the kinases; 2) inhibitors acting on several kinases of the cascade; 3) competitive or allosteric inhibitors; 4) inhibitors acting either on active or inactive forms of the cascade enzymes. We therefore tested several methodologies suitable for high-throughput screening to measure kinase activity. We chose and developed assays to measure the inhibitory effects of compounds on the whole cascade Raf/MEK/ERK, on the 
double cascade MEK/ERK and directly on the individual activities of Raf-1, MEK, and ERK. Finally, for each assay, three methods were assessed: the classical radioactive assay phosphocellulose filter-binding assay (PFBA) and two TRFRET methods: Lance ${ }^{\circledR}$ Ultra (Perkin Elmer, Waltham, MA) and LanthaScreen ${ }^{\mathrm{TM}}$ from Invitrogen (Carlsbad, CA). ${ }^{18-21}$ PFBA was used as a reference method because of its robustness. It is based on a direct detection of the radioactivity incorporated in substrates during kinase reaction, and it does not interfere with either colored or fluorescent compounds. However, the disadvantage of PFBA is its radioactivity handling (adenosine triphosphate [ATP] labeled with ${ }^{32} \mathrm{P}$ ) and several washings are required to remove excess radio-labeled ATP. On the contrary, TR-FRET is a technology more suitable for routine tests because it is sensitive, reliable, homogenous (no washing step), and compatible with high-throughput screening.

Because the three methods used different substrates and experimental conditions, it was not possible to consider comparing them directly, so we optimized each of the assays and we compared their efficiency to detect well known and commercially available inhibitors. To achieve this aim we tested compounds representative of the three types of kinase inhibitors currently classified as: (1) type I, inhibitors which bind exclusively to the ATP-binding site of the kinase; (2) type II, inhibitors which bind to an adjacent allosteric site of the ATP-binding site; (3) type III, inhibitors which bind to an allosteric site remote from the ATP. By comparison with the concentrations of a drug that is required for $50 \%$ inhibition values $\left(\mathrm{IC}_{50}\right)$ found in the literature and obtained with the PFBA method, we studied the capability of each TR-FRET assay to detect the different kinase inhibitors. A main conclusion of this work was that the TR-FRET assays on the triple cascade Raf/MEK/ERK could be useful to detect inhibitors of the whole cascade and also inhibitors of individual kinase, particularly MEK-1. Indeed, in the absence of MEK1 substrates well-adapted to detect inhibitors, the triple cascade Raf/MEK/ERK is suitable to study ATP competitive as well as allosteric inhibitors of MEK-1. Finally, the optimized and validated TR-FRET assays were used to screen newly synthesized inhibitors and to study the action of the phosphatidylethanolamine protein (PEBP), a natural inhibitor of the cascade Raf/MEK/ERK. PEBP is also called Raf kinase inhibitory protein (RKIP) and is known to take part in the accurate regulation of the Raf/ $\mathrm{MEK} / \mathrm{ERK}$ pathway by direct physical interaction with the kinases of the cascade. ${ }^{22-24}$

\section{Materials and methods}

\section{Enzymes and reagents}

Most of the human enzymes were purchased from Upstate (Millipore Billerica, MA), ie, constitutively active Raf-1 (306end, mutated Y340Y341D, specific activity $81414 \mathrm{U} / \mathrm{mg}$ ), fulllength active MEK-1 (specific activity $3272 \mathrm{U} / \mathrm{mg}$ ), inactive MEK-1, full-length active ERK-2 (specific activity $1410 \mathrm{U} / \mathrm{mg}$ ), and inactive ERK-2. Myelin basic protein (MBP) used as an ERK-2 substrate was also purchased from Upstate.

The $\gamma^{3}{ }^{32} \mathrm{P}$ ATP used for the PFBA method was purchased from Amersham (Piscataway, NJ) or from Perkin Elmer and incorporated radioactivity was measured using a Victor 14120 multilabel Wallac counter. To perform the TR-FRET tests, the Lance ${ }^{\circledR}$ Ultra from Perkin Elmer and the LanthaScreen ${ }^{\mathrm{TM}}$ method from Invitrogen were used. Consequently, for the Lance ${ }^{\circledR}$ Ultra assays, the ERK-2 substrate ULightMBP peptide (TRF0109), the Europium-labeled antibody anti-phosphorylated MBP [pThr ${ }^{232}$ ] (TRF0201), the Raf-1 substrate ULight-Histone H3 peptide (TRF0125), the Europium-labeled antibody antiphosphorylated Histone $\mathrm{H} 3$ [pThr ${ }^{3}$ ] (TRF0211), the MEK-1 substrate ULight-p70S6K peptide (TRF0126), and the Europium-labeled antibody antiphosphorylated p70S6K [pThr ${ }^{389}$ (TRF0214) were supplied by Perkin Elmer. Concerning the LanthaScreen ${ }^{\mathrm{TM}}$ assays, inactive fluorescein-labeled MEK-1 (PV4812) and Terbium-labeled antibody antiphosphorylated MEK-1 [pSer 217/221] (PV4817), needed for the direct Raf-1 assay were purchased from Invitrogen as GFP-ATF2 (PV4445), as well as the Terbium-labeled antibody antiphosphorylated ATF2 [pThr 71] (PV4451) needed for the direct ERK, the double cascade MEK/ERK, and the triple cascade Raf/MEK/ERK assays. All TR-FRET assays were performed in low volume white 384-well plates from Corning and time-resolved fluorescence was measured using a plate reader Victor $\mathrm{V}$ from Perkin Elmer.

Staurosporine, GW5074, ZM336372, U0126, MEK inhibitor II, PD98059, and FR180204 were purchased from Calbiochem (Gibbstown, NJ) while sorafenib was provided by the COMPISTO Company. Human PEBP/RKIP was prepared as previously described ${ }^{25}$ and was lyophilized; for each method, it was dissolved in the appropriate kinase buffer $(1 \mathrm{mg} / \mathrm{mL})$.

\section{PFBA determination of experimental conditions to measure the effect of inhibitors}

Five different tests were developed: 1) Raf-1 assay was performed with active Raf-1 and inactive MEK-1; 2) MEK-1 
assay, using active MEK-1 and inactive ERK-2; 3) ERK-2 assay with active ERK-2 and MBP; 4) MEK/ERK double cascade performed with active MEK-1, inactive ERK-2, and MBP; and 5) Raf/MEK/ERK triple cascade using active Raf-1, inactive MEK-1, inactive ERK-2, and MBP. First, the experimental conditions were optimized for each assay, and the capability of the optimized assays to detect commercially well known inhibitors was tested. Finally, the optimized and validated assays were used to measure the inhibitory effect of new synthesized compounds and of PEBP/RKIP (the natural inhibitor of the Raf/MEK/ERK pathway).

The kinases were diluted in the PFBA reaction buffer $1 \mathrm{X}$ (50 mM Tris/HCl pH 7.5, 0.1 mM EGTA, $0.1 \mathrm{mM} \mathrm{Na}_{3} \mathrm{VO}_{4}$, $0.1 \%$ mercaptoethanol, $0.01 \%$ Brij-35) to obtain $1.4 \mathrm{nM}$ to $250 \mathrm{nM}$ final concentration per assay. The ATP solution was prepared from a concentrated stock solution composed of $1 \mathrm{mM}$ ATP, $500 \mathrm{mM}$ MOPS pH 7.2, $50 \mathrm{mM} \mathrm{MgCl}_{2} \cdot{ }^{32} \mathrm{P}$ ATP was added at a final concentration of 0.05 to $0.5 \mu \mathrm{Ci}$ by assay. The inhibitors were first diluted at $25 \mu \mathrm{M}$ in dimethyl sulfoxide (DMSO) and further diluted solutions were prepared by 2.5 -fold serial dilution in DMSO. To measure the inhibitory effect of PEBP/RKIP, a mother solution $(1 \mathrm{mg} / \mathrm{mL}$ $(50 \mu \mathrm{M}))$ was prepared with the PFBA reaction buffer.

The experimental conditions were optimized for each PFBA assay: the obtained optimized volumes and concentrations are summarized in Table 1. The same process was followed to optimize assays and to measure the inhibitory effect of compounds. The experimental steps of this process, especially described for the evaluation of inhibitors, were as following. The assays were performed in a final volume of $25 \mu \mathrm{L}$ in $1.5 \mathrm{~mL}$ microtubes. First, $5 \mu \mathrm{L}$ of PFBA reaction buffer $5 \mathrm{X}$ containing $250 \mathrm{mM}$ Tris/ $\mathrm{HCl} \mathrm{pH} \mathrm{7.5,} 0.5 \mathrm{mM}$ EGTA, $0.5 \mathrm{mM} \mathrm{Na}_{3} \mathrm{VO}_{4}, 0.5 \%$ mercaptoethanol, 0.05\% Brij35 was added to each microtube. Then the active enzyme and inactive enzymes at optimal concentrations and MBP at Km concentration (Table 1) were incubated with the inhibitor to be tested. The reaction was started by adding ATP $(0.8 \mathrm{nM}$ to $0.33 \mu \mathrm{M})$. To test compound inhibition, $0.5 \mu \mathrm{L}$ of compound was used at a final concentration of $2 \%$ DMSO. The positive control was run with $2 \%$ DMSO and the negative control was run in the absence of the active kinase. To measure the inhibitory effect of PEBP/RKIP, the mother solution $(1 \mathrm{mg} / \mathrm{mL}$ $(50 \mu \mathrm{M}))$ was then diluted to have final concentrations from 0.64 to $25 \mu \mathrm{M}$ by the addition of $12.5 \mu \mathrm{L}$ of PEBP/RKIP solution in the assay. The positive control was run with $12.5 \mu \mathrm{L}$ of reaction buffer instead of PEBP/RKIP solution and the negative control was run in absence of the active kinase. The kinase reaction was terminated by the addition of $5 \mu \mathrm{L}$ of $50 \%$ phosphoric acid in each tube and $15 \mu \mathrm{L}$ of the terminated reaction was transferred to a phosphocellulose filter (Whatman ${ }^{\circledR}$ P81; Whatman, Piscataway, NJ). Each filter was washed twice for 5 minutes with $5 \mathrm{~mL}$ of $75 \mathrm{mM}$ phosphoric acid to wash away unreacted $\gamma-{ }^{32} \mathrm{P}$ ATP and once for 2 minutes with $2 \mathrm{~mL}$ methanol to remove trace of phosphoric acid. The

Table I PFBA assays, experimental conditions

\begin{tabular}{|c|c|c|c|c|c|c|c|c|}
\hline PFBA assay & $\begin{array}{l}\text { Enzyme } \\
\text { final conc. } \\
\text { volume }\end{array}$ & $\begin{array}{l}\text { Substrate I } \\
\text { final conc. } \\
\text { volume }\end{array}$ & $\begin{array}{l}\text { Substrate } 2 \\
\text { final conc. } \\
\text { volume }\end{array}$ & $\begin{array}{l}\text { Substrate } 3 \\
\text { final conc. } \\
\text { volume }\end{array}$ & $\begin{array}{l}\text { ATP } \\
\text { final conc.* } \\
\text { volume** }\end{array}$ & $\begin{array}{l}{ }^{32} \text { P ATP } \\
\text { final conc. }\end{array}$ & $\begin{array}{l}\text { Incubation } \\
\text { time, temp. }\end{array}$ & $\begin{array}{l}\text { Reaction } \\
\text { time, temp. }\end{array}$ \\
\hline \multirow[t]{3}{*}{ Direct Raf-I } & Raf-I & MEK-I & & & $0.25 \mu \mathrm{M}$ & $0.5 \mu \mathrm{Ci}$ & $20 \mathrm{~min}, \mathrm{RT}$ & $20 \mathrm{~min}, 30^{\circ} \mathrm{C}$ \\
\hline & $18.7 \mathrm{nM}$ & $0.25 \mu \mathrm{M}$ & & & I3.5 $\mu \mathrm{L}$ & & & \\
\hline & $3 \mu \mathrm{L}$ & $3 \mu \mathrm{L}$ & & & $6.5 \mu \mathrm{L}$ & & & \\
\hline \multirow[t]{3}{*}{ Direct MEK-I } & MEK-I & ERK-2, & & & $0.47 \mathrm{nM}$ & $0.05 \mu \mathrm{Ci}$ & $20 \mathrm{~min}, \mathrm{RT}$ & $10 \mathrm{~min}, 30^{\circ} \mathrm{C}$ \\
\hline & $0.25 \mu \mathrm{M}$ & $1.2 \mu \mathrm{M}$ & & & $9.5 \mu \mathrm{L}$ & & & \\
\hline & $5 \mu \mathrm{L}$ & $5 \mu \mathrm{L}$ & & & $2.5 \mu \mathrm{L}$ & & & \\
\hline \multirow[t]{3}{*}{ Direct ERK-2 } & ERK-2 & MBP, & & & $0.8 \mathrm{nM}$ & $0.1 \mu \mathrm{Ci}$ & $20 \mathrm{~min}, \mathrm{RT}$ & $10 \mathrm{~min}, 30^{\circ} \mathrm{C}$ \\
\hline & $0.25 \mu \mathrm{M}$ & $38 \mu \mathrm{M}$ & & & $9.5 \mu \mathrm{L}$ & & & \\
\hline & $5 \mu \mathrm{L}$ & $5 \mu \mathrm{L}$ & & & $2.5 \mu \mathrm{L}$ & & & \\
\hline MEK/ERK & MEK-I & ERK & MBP & & $19.5 \mathrm{nM}$ & $0.1 \mu \mathrm{Ci}$ & $20 \mathrm{~min}, \mathrm{RT}$ & $20 \mathrm{~min}, 30^{\circ} \mathrm{C}$ \\
\hline Double & $7.55 \mathrm{nM}$ & $50 \mathrm{nM}$ & $28.2 \mu \mathrm{M}$ & & $10 \mu \mathrm{L}$ & & & \\
\hline cascade & $5 \mu \mathrm{L}$ & $2.4 \mu \mathrm{L}$ & $2.6 \mu \mathrm{L}$ & & $2.5 \mu \mathrm{L}$ & & & \\
\hline Raf/MEK/ERK & Raf-I & MEK-I & ERK-2 & MBP & $0.33 \mu \mathrm{M}$ & $0.5 \mu \mathrm{Ci}$ & $20 \mathrm{~min}, \mathrm{RT}$ & $20 \mathrm{~min}, 30^{\circ} \mathrm{C}$ \\
\hline \multirow[t]{2}{*}{ Triple cascade } & $1.4 \mathrm{nM}$ & $7.55 \mathrm{nM}$ & $50 \mathrm{nM}$ & $28.2 \mu \mathrm{M}$ & $10 \mu \mathrm{L}$ & & & \\
\hline & $2 \mu \mathrm{L}$ & $2.5 \mu \mathrm{L}$ & $2.1 \mu \mathrm{L}$ & $2.9 \mu \mathrm{L}$ & $3 \mu \mathrm{L}$ & & & \\
\hline
\end{tabular}

Notes: Each assay was performed in a final volume of $25 \mu \mathrm{l}$. The kinases were diluted at the suitable concentration in the PFBA reaction buffer $(50 \mathrm{mMTris} / \mathrm{HCl} \mathrm{pH} 7.5, \mathrm{I} \mathrm{mM}$ EGTA, $10 \mathrm{mM} \mathrm{MgCl}$, $2 \mathrm{mM}$ DTT, 0.01\% Brij-35). The ATP solution was prepared from a stock solution composed of I mM ATP, $500 \mathrm{mM}$ MOPS pH 7.2, $50 \mathrm{mM}$ MgCl 2 . Inhibitory compounds were dissolved at $25 \mu \mathrm{M}$ in DMSO and further solutions were prepared by 2.5 -fold serial dilution. PEBP/RKIP was solubilized at I mg/mL ( $50 \mu \mathrm{M})$ in PFBA reaction buffer. *The final ATP concentration includes ${ }^{32}$ P ATP. **The first volume was used for chemical inhibitors; the second volume was used for PEBP/RKIP.

Abbreviations: Conc., concentration; temp., temperature; RT, room temperature. 
washes were performed in $15 \mathrm{~mL}$ conical tubes using a roller shaker. The filter was introduced in a scintillation vial and the filter-bound radioactivity was quantified using a Victor 14120 multilabel Wallac counter without the addition of scintillation cocktail.

\section{TR-FRET Lance ${ }^{\circledR}$ Ultra Perkin Elmer assays, determination of experimental conditions to measure the effect of inhibitors}

Five different tests were developed, as described above for the PFBA method. The optimal experimental conditions used to test the effects of inhibitors are detailed in Table 2. The assays were performed in a final volume of $10 \mu \mathrm{L}$ in lowvolume white 384-well plates. The kinases were diluted in the Lance ${ }^{\circledR}$ reaction buffer $(50 \mathrm{mM}$ Tris $/ \mathrm{HCl} \mathrm{pH} 7.5,1 \mathrm{mM}$ EGTA, $10 \mathrm{mM} \mathrm{MgCl}$, 2 mM DTT, 0.01\% Brij-35) to obtain 0.615 to $187 \mathrm{nM}$ final concentration per assay (Table 2). The ATP solution was prepared from a concentrated stock solution composed of $1 \mathrm{mM}$ ATP, $500 \mathrm{mM}$ MOPS pH 7.2, $50 \mathrm{mM}$ $\mathrm{MgCl}_{2}$. All the Europium-labeled antibodies were diluted in the TR-FRET detection buffer 1X (CR97-100, Perkin Elmer). The inhibitors were first diluted at $25 \mu \mathrm{M}$ in DMSO and further diluted solutions were prepared by 2.5 -fold serial dilution in DMSO. A mother solution of PEBP/RKIP $(1 \mathrm{mg} / \mathrm{mL}$ $(50 \mu \mathrm{M}))$ was prepared in the Lance ${ }^{\circledR}$ reaction buffer.
The same process was followed to optimize assays and to measure the inhibitory effect of compounds. The detailed operation steps, described for the evaluation of inhibitors, follow. Optimal concentrations of the active enzyme and the inactive enzymes (intermediate substrates) were incubated with a chemical inhibitor or PEBP/RKIP for 20 minutes at room temperature (Table 2 ). The enzyme reaction was initiated by adding final ULight-substrate and ATP at Km concentrations (100 to $334 \mathrm{nM}$ ULight-substrate and 0.354 to $24.7 \mu \mathrm{M}$ ATP according to the assay) and was run at room temperature for 30 to 60 minutes (Table 2). To test compound inhibition, $0.5 \mu \mathrm{L}$ of the compound was used at a final concentration of $5 \%$ DMSO. The positive control was run with $5 \%$ DMSO and the negative control was run in absence of the active kinase. To measure the inhibitory effect of PEBP/ RKIP, the protein was solubilized in the Lance ${ }^{\circledR}$ reaction buffer to final concentrations of 0.64 to $25 \mu \mathrm{M}$ when $5 \mu \mathrm{L}$ of PEBP/RKIP solution was added. The positive control was run with $5 \mu \mathrm{L}$ of Lance $^{\circledR}$ reaction buffer instead of PEBP/ RKIP and the negative control was run in the absence of the active kinase. A preparation of $10 \mu \mathrm{L}$, containing $5 \mu \mathrm{L}$ of $40 \mathrm{mM}$ ethylenediaminetetraacetic acid (EDTA) and $5 \mu \mathrm{L}$ of $8 \mathrm{nM}$ Europium-labeled antibody directed against the phosphorylated ULight-substrate, was added to terminate the kinase reaction. The final concentrations of EDTA and antibodies in the assays were $20 \mathrm{mM}$ and $4 \mathrm{nM}$, respectively. The plate was allowed to incubate at room temperature for

Table 2 Lance ${ }^{\circledR}$ Ultra assays, experimental conditions

\begin{tabular}{|c|c|c|c|c|c|c|c|}
\hline $\begin{array}{l}\text { Lance }{ }^{\circledR} \text { Ultra } \\
\text { assay }\end{array}$ & $\begin{array}{l}\text { Enzyme } \\
\text { final conc. } \\
\text { volume* }\end{array}$ & $\begin{array}{l}\text { Substrate I } \\
\text { final conc. } \\
\text { volume* }\end{array}$ & $\begin{array}{l}\text { Substrate } 2 \\
\text { final conc. } \\
\text { volume* }\end{array}$ & $\begin{array}{l}\text { Substrate } 3 \\
\text { final conc. } \\
\text { volume* }\end{array}$ & $\begin{array}{l}\text { ATP } \\
\text { final conc. } \\
\text { volume* }\end{array}$ & $\begin{array}{l}\text { Incubation } \\
\text { time, temp. }\end{array}$ & $\begin{array}{l}\text { Reaction } \\
\text { time, temp. }\end{array}$ \\
\hline \multirow[t]{3}{*}{ Direct Raf-I } & Raf-I & Ulight-histone $\mathrm{H} 3$ & & & $17 \mu \mathrm{M}$ & $20 \mathrm{~min}, \mathrm{RT}$ & $60 \mathrm{~min}, \mathrm{RT}$ \\
\hline & $20 \mathrm{nM}$ & $119 \mathrm{nM}$ & & & $2 \mu \mathrm{L}, \mathrm{nd}$ & & \\
\hline & $5 \mu \mathrm{L}, \mathrm{nd}$ & $2.5 \mu \mathrm{L}, \mathrm{nd}$ & & & & & \\
\hline \multirow[t]{3}{*}{ Direct MEK-I } & MEK-I & Ulight- p70S6K & & & $24.7 \mu \mathrm{M}$ & $20 \mathrm{~min}, \mathrm{RT}$ & $30 \mathrm{~min}, \mathrm{RT}$ \\
\hline & $100 \mathrm{nM}$ & $334 \mathrm{nM}$ & & & $2 \mu \mathrm{L}, \mathrm{nd}$ & & \\
\hline & $5 \mu \mathrm{L}, \mathrm{nd}$ & $2.5 \mu \mathrm{L}, \mathrm{nd}$ & & & & & \\
\hline \multirow[t]{3}{*}{ Direct ERK-2 } & ERK-2 & Ulight-MBP & & & 354 nM & $20 \mathrm{~min}, \mathrm{RT}$ & $30 \mathrm{~min}, \mathrm{RT}$ \\
\hline & 187 nM & $100 \mathrm{nM}$ & & & $2 \mu \mathrm{L}, \mathrm{I} \mu \mathrm{L}$ & & \\
\hline & $5 \mu \mathrm{L}, 2 \mu \mathrm{L}$ & $2.5 \mu \mathrm{L}, 2 \mu \mathrm{L}$ & & & & & \\
\hline MEK/ERK & MEK-I & ERK-2 & Ulight-MBP & & $5.5 \mu \mathrm{M}$ & $20 \mathrm{~min}, \mathrm{RT}$ & $60 \mathrm{~min}, \mathrm{RT}$ \\
\hline \multirow[t]{2}{*}{ Double cascade } & $2,56 \mathrm{nM}$ & 187 nM & $100 \mathrm{nM}$ & & $\mathrm{I} \mu \mathrm{L}, \mathrm{I} \mu \mathrm{L}$ & & \\
\hline & $5 \mu \mathrm{L}, 2 \mu \mathrm{L}$ & $2 \mu \mathrm{L}, \mathrm{I} \mu \mathrm{L}$ & I. $5 \mu \mathrm{L}, \mathrm{I} \mu \mathrm{L}$ & & & & \\
\hline Raf/MEK/ERK & Raf-I & MEK-I & ERK-2 & Ulight-MBP & $5 \mu \mathrm{M}$ & $20 \mathrm{~min}, \mathrm{RT}$ & $50 \mathrm{~min}, \mathrm{RT}$ \\
\hline \multirow[t]{2}{*}{ Triple cascade } & $0.615 \mathrm{nM}$ & $2.56 \mathrm{nM}$ & 187 nM & $100 \mathrm{nM}$ & $0.5 \mu \mathrm{L}, \mathrm{I} \mu \mathrm{L}$ & & \\
\hline & $4 \mu \mathrm{L}, \mathrm{I} \mu \mathrm{L}$ & $2 \mu \mathrm{L}, \mathrm{I} \mu \mathrm{L}$ & $2 \mu \mathrm{L}, \mathrm{I} \mu \mathrm{L}$ & $\mathrm{I} \mu \mathrm{L}, \mathrm{I} \mu \mathrm{L}$ & & & \\
\hline
\end{tabular}

Notes: Each assay was performed in a final volume of $10 \mu \mathrm{L}$. The kinases were diluted at the suitable concentration in the Lance ${ }^{\circledR} \mathrm{Ultra}$ reaction buffer: $50 \mathrm{mM}$ Tris/ $\mathrm{HCl} \mathrm{pH}$ 7.5, I mM EGTA, $10 \mathrm{mM} \mathrm{MgCl}$, 2 mM DTT, 0.01\% Brij-35. The ATP solution was prepared from a stock solution composed of I mMATP, $500 \mathrm{mM}$ MOPS pH 7.2, $50 \mathrm{mM}$ MgCl . Inhibitory compounds were dissolved at $25 \mu \mathrm{M}$ in DMSO and further solutions were prepared by 2.5 -fold serial dilution. PEBP/RKIP was solubilized at I mg/mL ( $50 \mu \mathrm{M})$ in Lance $^{\circledR}$ Ultra reaction buffer. *The first volume was used for chemical inhibitors and the second volume was used for PEBP/RKIP. nd; not determined because the assay was not sensitive enough to measure the inhibitory effect of PEBP/RKIP.

Abbreviations: Conc., concentration; RT, room temperature; nd, not determined. 
20 minutes. The fluorescence signal was then measured using a Perkin Elmer Victor $\mathrm{V}^{\mathrm{TM}}$ plate reader using an excitation wavelength of $340 \mathrm{~nm}$ and emission wavelengths of $615 \mathrm{~nm}$ and $665 \mathrm{~nm}$.

\section{TR-FRET LanthaScreen ${ }^{\text {TM }}$ Invitrogen assays, determination of experimental conditions to measure the effect of inhibitors}

Four different assays were developed: Raf-1, ERK-2, MEK/ERK double cascade, and Raf/MEK/ERK triple cascade. LanthaScreen ${ }^{\mathrm{TM}}$ MEK-1 kinase assay was not tested because the fluorescein-ERK2 or GFP-ERK2 needed as the MEK-1 substrate was not commercially available.

LanthaScreen $^{\mathrm{TM}}$ kinase assays were performed in a final volume of $10 \mu \mathrm{L}$ in low-volume white 384-well plates. All the kinases were diluted in the LanthaScreen ${ }^{\mathrm{TM}}$ reaction buffer (50 mM HEPES pH 7.5, 1 mM EGTA, $10 \mathrm{mM} \mathrm{MgCl}, 2 \mathrm{mM}$ DTT, $0.01 \%$ Brij-35) to obtain 0.2 to $50 \mathrm{nM}$ according to the assay (Table 3 ). The ATP solution was prepared from a concentrated stock solution composed of $1 \mathrm{mM}$ ATP, $500 \mathrm{mM}$ MOPS pH 7.2, $50 \mathrm{mM}$ $\mathrm{MgCl}_{2}$. All the terbium-labeled antibodies were diluted in the TR-FRET detection buffer (PV3574, Invitrogen). The inhibitors were first diluted at $25 \mu \mathrm{M}$ in DMSO and further diluted solutions were prepared by 2.5 -fold serial dilution in DMSO. A mother solution of PEBP/RKIP $(1 \mathrm{mg} / \mathrm{mL}(50 \mu \mathrm{M}))$ was prepared in the LanthaScreen ${ }^{\mathrm{TM}}$ reaction buffer.
The experimental process was as follows. Active enzyme and inactive enzymes (intermediate substrates) at optimal concentrations were incubated with a chemical inhibitor or PEBP/RKIP during 20 minutes at room temperature (Table 3). The enzyme reaction was started by adding ATP (75 nM to $27 \mu \mathrm{M}$ ) and the final fluorescent substrate labeled with fluorescein or GFP at Km concentrations (40 nM), followed by the kinase reaction run at room temperature during 45 to 80 minutes (Table 3). To test compound inhibition, $0.5 \mu \mathrm{L}$ of the compound was used at a final concentration of $5 \%$ DMSO; the positive control was run with 5\% DMSO and the negative control was run in the absence of the active kinase. To measure the inhibitory effect of PEBP/RKIP, the protein was diluted in the LanthaScreen ${ }^{\mathrm{TM}}$ reaction buffer to final concentrations of 0.64 to $25 \mu \mathrm{M}$ when adding $5 \mu \mathrm{L}$ of the PEBP/RKIP solution; the positive control was run with $5 \mu \mathrm{L}$ of LanthaScreen ${ }^{\mathrm{TM}}$ reaction buffer instead of protein solution and the negative control was run in the absence of the active kinase. All the kinase reactions were stopped by adding $10 \mu \mathrm{L}$ of a solution containing $5 \mu \mathrm{L}$ of $40 \mathrm{mM}$ EDTA and $5 \mu \mathrm{L}$ of $8 \mathrm{nM}$ terbium-labeled antibody. The plate was allowed to incubate at room temperature for at least 20 minutes. The fluorescence detection was performed with a Perkin Elmer Victor $\mathrm{V}^{\mathrm{TM}}$ plate reader using an excitation wavelength of $340 \mathrm{~nm}$ and emission wavelengths of $445 \mathrm{~nm}$ and $520 \mathrm{~nm}$.

\section{Data analysis}

All the experiments, ie, titration of enzymes and substrates, ATP, time course of kinase reactions, and inhibition curves,

Table 3 LanthaScreen ${ }^{\mathrm{TM}}$ assays, experimental conditions

\begin{tabular}{|c|c|c|c|c|c|c|c|}
\hline $\begin{array}{l}\text { Lanthascreen }^{\mathrm{TM}} \\
\text { assay }\end{array}$ & $\begin{array}{l}\text { Enzyme } \\
\text { final conc. } \\
\text { volume* }\end{array}$ & $\begin{array}{l}\text { Substrate I } \\
\text { final conc. } \\
\text { volume* }\end{array}$ & $\begin{array}{l}\text { Substrate } 2 \\
\text { final conc. } \\
\text { volume* }\end{array}$ & $\begin{array}{l}\text { Substrate } 3 \\
\text { final conc. } \\
\text { volume* }\end{array}$ & $\begin{array}{l}\text { ATP } \\
\text { final conc. } \\
\text { volume* }\end{array}$ & $\begin{array}{l}\text { Incubation } \\
\text { time, temp. }\end{array}$ & $\begin{array}{l}\text { Reaction } \\
\text { time, temp. }\end{array}$ \\
\hline \multirow[t]{3}{*}{ Direct Raf-I } & Raf-I & Fluorescein-MEKI & & & $0.075 \mu \mathrm{M}$ & $20 \mathrm{~min}, \mathrm{RT}$ & $45 \min , \mathrm{RT}$ \\
\hline & $3.8 \mathrm{nM}$ & $40 \mathrm{nM}$ & & & $2 \mu \mathrm{L}, \mathrm{I} \mu \mathrm{L}$ & & \\
\hline & $5 \mu \mathrm{L}, 2 \mu \mathrm{L}$ & $2.5 \mu \mathrm{L}, 2 \mu \mathrm{L}$ & & & & & \\
\hline \multirow[t]{3}{*}{ Direct ERK-2 } & ERK-2 & GFP-ATF2 & & & $421 \mathrm{nM}$ & $20 \mathrm{~min}, \mathrm{RT}$ & $50 \mathrm{~min}, \mathrm{RT}$ \\
\hline & $50 \mathrm{nM}$ & $40 \mathrm{nM}$ & & & $2 \mu \mathrm{L}, \mathrm{I} \mu \mathrm{L}$ & & \\
\hline & $5 \mu \mathrm{L}, 2 \mu \mathrm{L}$ & $2.5 \mu \mathrm{L}, 2 \mu \mathrm{L}$ & & & & & \\
\hline MEK/ERK & MEK-I & ERK-2 & GFP-ATF2 & & $4.4 \mu \mathrm{M}$ & $20 \mathrm{~min}, \mathrm{RT}$ & $80 \mathrm{~min}, \mathrm{RT}$ \\
\hline \multirow[t]{2}{*}{ Double cascade } & $1.13 \mathrm{nM}$ & $50 \mathrm{nM}$ & $40 \mathrm{nM}$ & & $\mathrm{I} \mu \mathrm{L}, \mathrm{I} \mu \mathrm{L}$ & & \\
\hline & $5 \mu \mathrm{L}, 2 \mu \mathrm{L}$ & $2 \mu \mathrm{L}, \mathrm{I} \mu \mathrm{L}$ & I.5 $\mu \mathrm{L}, \mathrm{I} \mu \mathrm{L}$ & & & & \\
\hline Raf/MEK/ERK & Raf-I & MEK-I & ERK-2 & GFP-ATF2 & $27 \mu \mathrm{M}$ & $20 \mathrm{~min}, \mathrm{RT}$ & $80 \mathrm{~min}, \mathrm{RT}$ \\
\hline \multirow[t]{2}{*}{ Triple cascade } & $0.2 \mathrm{nM}$ & $1.13 \mathrm{nM}$ & $50 \mathrm{nM}$ & $40 \mathrm{nM}$ & $0.5 \mu \mathrm{L}, \mathrm{I} \mu \mathrm{L}$ & & \\
\hline & $4 \mu \mathrm{L}, \mathrm{I} \mu \mathrm{L}$ & $2 \mu \mathrm{L}, \mathrm{I} \mu \mathrm{L}$ & $2 \mu \mathrm{L}, I \mu \mathrm{L}$ & $I \mu \mathrm{L}, \mathrm{I} \mu \mathrm{L}$ & & & \\
\hline
\end{tabular}

Notes: Each assay was performed in a final volume of $10 \mu \mathrm{L}$. The kinases were diluted at the suitable concentration in the LanthaScreen ${ }^{\text {TM }}$ reaction buffer: $50 \mathrm{mM}$ HEPES $\mathrm{pH}$ 7.5, I mM EGTA, $10 \mathrm{mM} \mathrm{MgCl}, 2 \mathrm{mM} \mathrm{DTT,} 0.01 \% \mathrm{Brij}_{2} 35$. The ATP solution was prepared from a stock solution composed of I mM ATP, $500 \mathrm{mM}$ MOPS pH 7.2, $50 \mathrm{mM} \mathrm{MgCl}$. Inhibitory compounds were dissolved at $25 \mu \mathrm{M}$ in DMSO and further solutions were prepared by 2.5 -fold serial dilution. PEBP/RKIP was solubilized at I $\mathrm{mg} / \mathrm{mL}$ ( $50 \mu \mathrm{M})$ in LanthaScreen ${ }^{\mathrm{TM}}$ reaction buffer. ${ }^{*}$ The first volume was used for chemical inhibitors; the second volume was used for PEBP/RKIP.

Abbreviations: Conc., concentration; RT, room temperature. 
were performed in triplicate. All data were plotted and analyzed using Kaleidagraph ${ }^{\circledR}$ software (Synergy Software, Reading, PA). For each well, the percent of inhibition was calculated using the following equations (1) for the TR-FRET assays and ( $\left.1^{\prime}\right)$ for the radioactive assay.

$$
\begin{aligned}
\% \text { inhibition }= & 100-\left(\left(\left(\text { Em. ratio }-\mu \mathrm{c}^{-}\right) \times 100\right) /\right. \\
& \left.\left(\mu \mathrm{c}^{+}-\mu \mathrm{c}^{-}\right)\right)
\end{aligned}
$$

in which Em. ratio is the ratio of ULight/Europium (665 $\mathrm{nm} / 615 \mathrm{~nm}$ ) emission signal intensities for the Lance $^{\circledR}$ Ultra assay or the ratio fluorescein or GFP/terbium $(520 \mathrm{~nm} / 495 \mathrm{~nm})$ for the LanthaScreen ${ }^{\mathrm{TM}}$ assay; $\mu \mathrm{c}^{-}$is the average of the negative control (100\% inhibition); $\mu \mathrm{c}^{+}$is the average of the positive control ( $0 \%$ inhibition).

$$
\begin{aligned}
\% \text { inhibition }= & 100-\left(\left(\left(\mathrm{cpm}-\mu \mathrm{c}^{-}\right) \times 100\right) /\right. \\
& \left.\left(\mu \mathrm{c}^{+}-\mu \mathrm{c}^{-}\right)\right)
\end{aligned}
$$

in which cpm is the counts per minute signal intensity measured in the radioactive assay PFBA; $\mu \mathrm{c}^{-}$is the average of the negative control ( $100 \%$ inhibition); $\mu \mathrm{c}^{+}$is the average of the positive control ( $0 \%$ inhibition).

To obtain the $\mathrm{IC}_{50}$ curves, the data were fitted using an hyberbolic equation (2) or a sigmoidal equation (3) according to the type of inhibitors:

$$
\begin{gathered}
\mathrm{Y}=100 * \mathrm{x} /(\mathrm{b}+\mathrm{x}) ; \mathrm{b}=\mathrm{IC}_{50} \\
\mathrm{Y}=(100 * \mathrm{x})^{\mathrm{b}} /\left(\mathrm{C}^{\mathrm{b}}+\mathrm{x}^{\mathrm{b}}\right) ; \mathrm{b}=\text { Hill number; } \mathrm{C}=\mathrm{IC}_{50}
\end{gathered}
$$

$\mathrm{Z}^{\prime}$ factors were calculated according to the equation (4) where $\sigma$ is the standard deviation and $\mu$ is the mean of the positive $\left(\mathrm{c}^{+}\right)$or the negative $\left(\mathrm{c}^{-}\right)$controls. ${ }^{26}$ The negative controls $\left(\mathrm{c}^{-}\right)$were calculated in the presence of $2 \mu \mathrm{M}$ of sorafenib, corresponding to $100 \%$ inhibition whereas the positive controls $\left(\mathrm{c}^{+}\right)$were calculated in the absence of the inhibitor sorafenib corresponding to $0 \%$ inhibition.

$$
Z^{\prime}=1-\left[\left(3 \sigma_{\mathrm{c}^{+}}+3 \sigma_{\mathrm{c}^{-}}\right) /\left(\mu \mathrm{c}^{+}-\mu \mathrm{c}^{-}\right)\right]
$$

The $Z^{\prime}$ factor is an attempt to quantify the suitability of a particular assay for use in a full-scale, high-throughput screen. A $Z^{\prime}$ factor between 0.5 and 1 indicates a high signal difference between positive and negative controls that is favorable for suitable assay reproducibility.

\section{Results \\ Choice of method}

In this work, our goal was to develop assays suitable to detect inhibitors of the whole Raf/MEK/ERK cascade as well as inhibitors of each separate enzyme. All the kinase assays described here were optimized and evaluated for their capability to detect inhibitors. The phosphocellulose filter-binding assay (PFBA) was used as a reference method because it is a conventional technique using radioactivity. Briefly, an aliquot of the kinase assay was transferred onto a phosphocellulose paper filter that was then washed three times and the remaining radioactivity due to substrate phosphorylation was quantified using a scintillation counter.

Lance $^{\circledR}$ Ultra and LanthaScreen ${ }^{\mathrm{TM}}$ methods, more suitable than PFBA for high throughput screening, were chosen. These two methods are based on the TR-FRET homogenous technology, illustrated in (Figure 2). Both Lance ${ }^{\circledR}$ Ultra and LanthaScreen ${ }^{\mathrm{TM}}$ methods use antiphosphosubstrate antibodies labeled with a donor dye and substrates labeled with an acceptor dye. In the presence of kinase(s) and ATP, the substrate is phosphorylated and recognized by its specific antibody which brings the donor and acceptor dyes in close proximity. Upon excitation at $340 \mathrm{~nm}$, the donor transfers its energy to the acceptor dye, resulting in a fluorescent light emission from the acceptor. TR-FRET technologies use lanthanides (ie, europium, terbium) as donor dyes because they have large Stoke's shifts and long-lived emission fluorescence. The use of long-lived fluorophores combined with a time-resolved detection (a time delay of 50 to $150 \mu$ seconds between excitation and emission detection) minimizes background or prompt fluorescence. Lance ${ }^{\circledR}$ Ultra technology uses europium as the donor dye and a new ULight ${ }^{\mathrm{TM}}$ dye as the acceptor. ULight is a small acceptor dye with spectral characteristics similar to allophycocyanin. LanthaScreen ${ }^{\mathrm{TM}}$ technology uses terbium as the donor dye and fluorescein or GFP as the acceptor dye. One advantage of these technologies is the ability to monitor the fluorescence of both the acceptor and donor dyes, which allows a ratiometric correction for liquid dispensing errors, reducing assay variability. Consequently, the emission ratio (acceptor emission/donor emission) calculation is currently used by TRFRET technologies. In all the assays presented in this paper, the $665 / 615 \mathrm{~nm}$ ratio and the $520 / 495 \mathrm{~nm}$ ratio were calculated for Lance ${ }^{\circledR}$ Ultra and LanthaScreen ${ }^{\mathrm{TM}}$, respectively.

\section{Strategy for the optimization and evaluation of the Raf-I, MEK-I and ERK-2 direct assays}

The three direct assays on Raf-1, MEK-1, and ERK-2 were optimized for each of the three methods PFBA, Lance ${ }^{\circledR}$ Ultra, and LanthaScreen. ${ }^{\mathrm{TM}}$ The same four steps approach was followed. The first step was the double titration of both active enzyme and substrate at a nonlimiting concentration of ATP in order to determine the optimal enzyme concentration and the apparent $\mathrm{Km}$ for the substrate. The enzyme concentration 


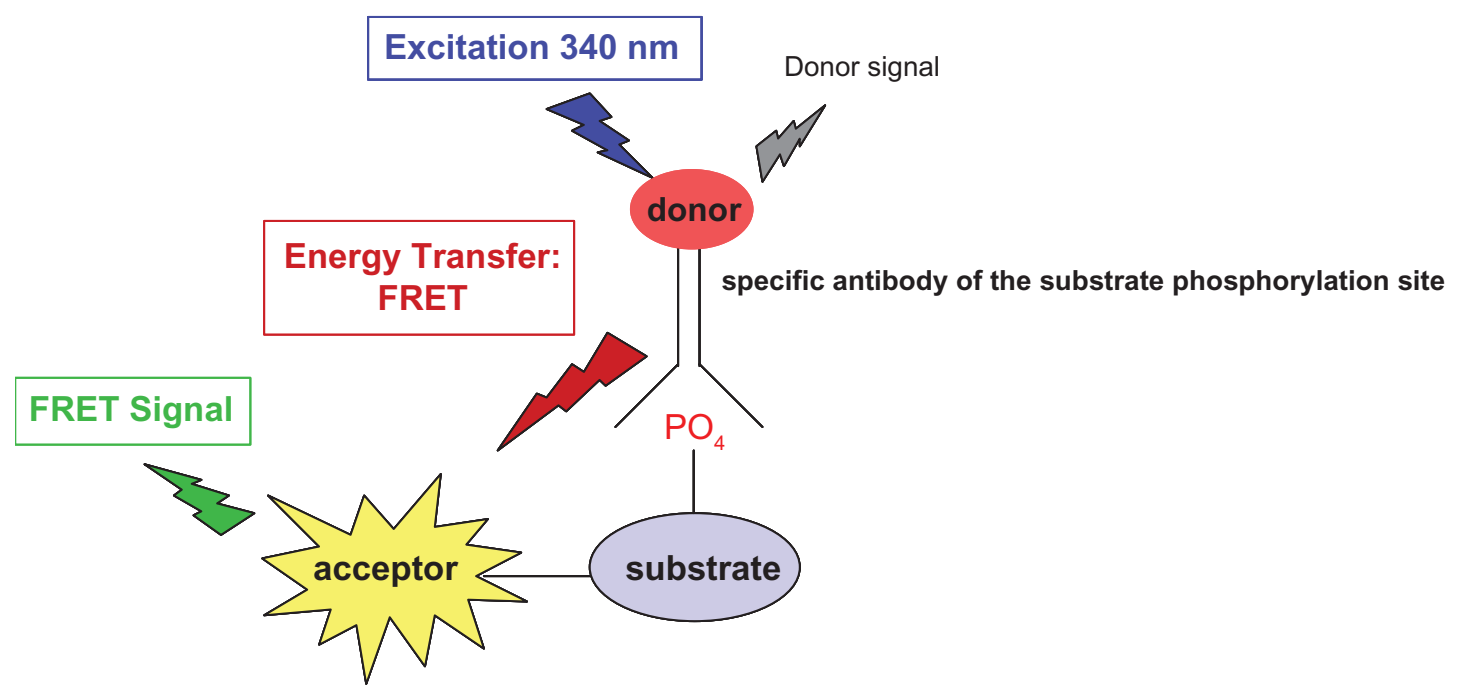

\begin{tabular}{|l|c|c|}
\hline & $\begin{array}{c}\text { LanthaScreen } \\
\text { Invitrogen }\end{array}$ & $\begin{array}{c}\text { Lance }^{\circledR} \text { Ultra } \\
\text { PerkinElmer }^{\mathrm{TM}}\end{array}$ \\
\hline Donor dye & Terbium & Europium \\
\hline Acceptor dye & Fluorescein or GFP & Ulight \\
\hline Excitation & $340 \mathrm{~nm}$ & $340 \mathrm{~nm}$ \\
\hline Emission & $520 \mathrm{~nm}$ (FRET signal) & $\begin{array}{c}665 \mathrm{~nm} \text { (FRET signal) } \\
615 \mathrm{~nm} \text { (Europium signal) }\end{array}$ \\
\hline
\end{tabular}

Figure 2 Principle of the time-resolved fluorescence resonance energy transfer (TR-FRET) technology; comparison of LanthaScreen ${ }^{T M}$ and Lance ${ }^{\circledR}$ Ultra methods. Excitation of the donor dye leads to an energy transfer to the acceptor dye when it is in close proximity with the donor, resulting in a light emission proportional to the level of substrate phosphorylation. The use of donor dyes with a long-lived fluorescence (ie, europium and terbium) combined with time-resolved detection minimizes background interference. These TR-FRET assays differ principally in the nature of the acceptor dye used for the energy transfer (fluorescein or green fluorescent protein (GFP) in LanthaScreen ${ }^{\text {TM }}$ method, ULight ${ }^{\mathrm{TM}}$ in Lance ${ }^{\circledR}$ Ultra method), and in the nature of the substrate (protein or peptide).

needed was determined in order to have the best sensitivity using the smallest quantity of enzyme. The second step was the ATP titration to determinate its apparent $\mathrm{Km}$ value. The third step was the time course monitoring of the substrate phosphorylation in order to choose a time reaction in the linear range. The fourth step was the evaluation control by measuring the effect of reported inhibitors on enzyme activity. In order to have a high level of sensitivity, compatible with the detection of inhibitors, all the inhibition assays were performed at the optimal enzyme concentrations, $\mathrm{Km}$ of substrate and ATP, and in a linear range of time reaction.

\section{Results for the optimization and evaluation of the Raf-I direct assays}

When the direct Raf-1 kinase assays were performed, the phosphorylated substrate was the protein MEK-1, the peptide ULight-Histone H3, and the protein Fluorescein-MEK-1 for PFBA, Lance ${ }^{\circledR}$ Ultra, and LanthaScreen ${ }^{\mathrm{TM}}$ methods respectively. As an example, Figure 3 presents the curves obtained for the direct Raf-1 assay optimization with the PFBA method. The first step was the optimization of the amount of Raf-1 and MEK-1 (Figure 3a). This assay was performed varying the amount of active Raf- 1 from 0 to 43 $\mathrm{nM}$ and inactive MEK-1 from 0 to $0.77 \mu \mathrm{M}$ in the presence of nonlimiting ATP concentration. $18.7 \mathrm{nM}$ appeared to be the optimal Raf-1 concentration and the apparent $\mathrm{Km}$ for MEK-1 was $0.25 \mu \mathrm{M}$. Thus, we selected these enzyme and substrate concentrations for the ATP titration assay. An apparent Km value of $0.25 \mu \mathrm{M}$ was obtained for ATP (Figure 3b). As the last step of the optimization, a time course of MEK-1 phosphorylation was performed. The Raf-1 direct kinase reaction was linear for up to 30 minutes at $30^{\circ} \mathrm{C}$ (Figure 3c). Based on these results, a time incubation of 20 minutes at $30^{\circ} \mathrm{C}$ was chosen. Further $\mathrm{IC}_{50}$ measurements of the Raf- 1 
A

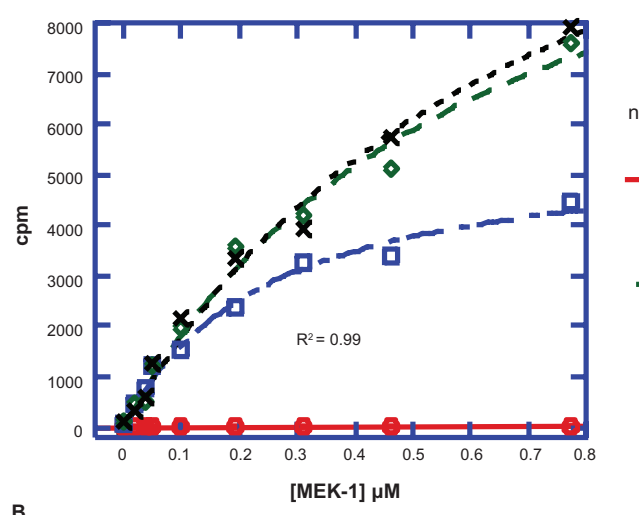

B

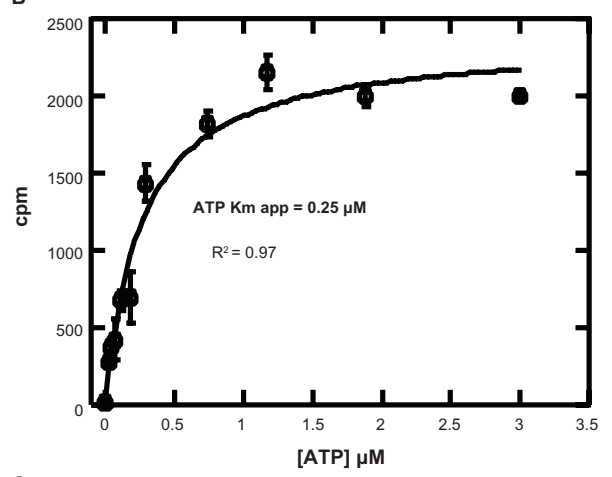

C

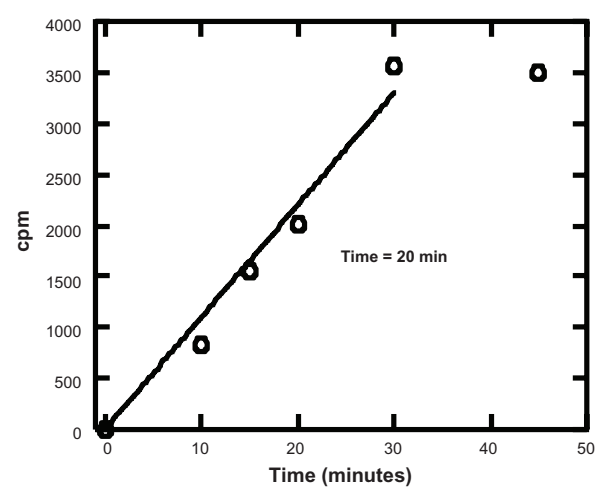

Figure 3 Optimization of the direct Raf-I phosphocellulose filter binding assay (PFBA) The coefficient of determination $\mathrm{R}^{2}$ is shown and error bars represent standard deviation obtained from 3 different assays. The reactions were stopped after 20 minutes at $30^{\circ} \mathrm{C}$ by addition of $5 \mu \mathrm{L}$ of $50 \%$ phosphoric acid. The ${ }^{32} \mathrm{P}$ incorporated by MEK-I during the kinase reaction was quantified using a scintillation counter without addition of scintillation cocktail. A) Optimization of active Raf-I and MEK-I substrate amounts. Active Raf-I was titrated from 0 to $43 \mathrm{nM}$ and inactive MEK-I from 0 to $0.77 \mu \mathrm{M}$ in presence of nonlimiting $2 \mu \mathrm{M}$ adenosine triphosphate (ATP) and $0.5 \mu \mathrm{Ci} \gamma$ - $^{32} \mathrm{P}$ ATP per tube. B) ATP titration. Diluted ATP was added in assay reactions containing $18.7 \mathrm{nM}$ active Raf- $\mathrm{I}$ and $0.25 \mu \mathrm{M}$ inactive MEK-I. ATP was varied from 0 to $3 \mu \mathrm{M}$ with $0.5 \mu \mathrm{Ci} \gamma-{ }^{32} \mathrm{P}$ ATP per tube C) Time course of the Raf-I kinase reaction. The assay was performed using the optimized concentrations of $18.7 \mathrm{nM}$ active Raf-I, $0.25 \mu \mathrm{M}$ inactive MEK-I, and $0.25 \mu \mathrm{M}$ ATP with $0.5 \mu \mathrm{Ci} \gamma-{ }^{32} \mathrm{PATP}$ per tube. Reactions were terminated at specific time points by the addition of $5 \mu \mathrm{L}$ of $50 \%$ phosphoric acid.

inhibitors were performed at the Km values for both ATP and MEK-1 and at the initial speed of the kinase reaction. All these experimental conditions are summarized in the first line of Table 1 and were used for further evaluation of inhibitors. The same process was applied for the optimization of the direct Raf-1 kinase assay with the Lance ${ }^{\circledR}$ Ultra method (curves not shown). The cross-titration of Raf- 1 and ULightHistone $\mathrm{H} 3$ substrate was performed by varying the amount of Raf- 1 from 0 to $20 \mathrm{nM}$ and ULight-Histone $\mathrm{H} 3$ from 0 to $300 \mathrm{nM}$ in the presence of a nonlimiting ATP concentration. On the basis of these results, we chose concentrations of $20 \mathrm{nM}$ Raf-1 and $0.119 \mu \mathrm{M}$ ULight-Histone H3 (apparent $\mathrm{Km})$. In these conditions, an apparent $\mathrm{Km}$ value of $16.9 \mu \mathrm{M}$ was obtained for ATP. The time course of ULight-Histone $\mathrm{H} 3$ phosphorylation was performed at room temperature, the Raf-1 kinase reaction was linear up to 90 minutes. Based on these results, the further inhibition studies were performed in conditions described in Table 2 (line 1).

The LanthaScreen ${ }^{\mathrm{TM}}$ method uses the entire MEK-1 protein labeled with fluorescein as an Raf-1 substrate. The cross-titration of Raf-1 and Fluorescein-MEK-1 protein substrate was performed varying the amount of Raf- 1 from 0 to $30.8 \mathrm{nM}$ and the Fluorescein-MEK- 1 from 0 to $0.8 \mu \mathrm{M}$ in the presence of nonlimiting ATP concentration. We thus chose $3.8 \mathrm{nM}$ as the optimal Raf- 1 concentration and the apparent Km for Fluorescein-MEK-1 substrate was determined to be $40 \mathrm{nM}$. An apparent $\mathrm{Km}$ value of $0.075 \mu \mathrm{M}$ was obtained for ATP. The Raf-1 direct kinase reaction was linear up to 60 minutes at room temperature. These conditions are indicated in Table 3, line 1. Further inhibitory studies were therefore performed in these optimized conditions.

The effects of five commercially available Raf- 1 inhibitors, namely sorafenib, GW5074, ZM336372, U0126, and MEK II inhibitor, were tested in order to validate the optimized Raf-1 direct assays. The obtained results are shown in Table 4. As expected, the ATP competitive inhibitors sorafenib, GW5074, and ZM336372 were detected as strong Raf-1 inhibitors. ${ }^{27-29}$ The results obtained with PFBA and LanthaScreen ${ }^{\mathrm{TM}}$ methods were coherent between themselves and consistent with the reported $\mathrm{IC}_{50}$ values. In order to know whether the PFBA and TR-FRET assays were able to characterize a weaker inhibitor of Raf-1, MEK inhibitor II was tested. ${ }^{30}$ The expected $\mathrm{IC}_{50}$ values were obtained for the MEK inhibitor II with the PFBA and LanthaScreen ${ }^{\mathrm{TM}}$ methods. The Lance ${ }^{\circledR}$ Ultra Raf-1 assay was not able to reveal any of the tested Raf- 1 inhibitors (even the very strong inhibitor sorafenib). This unsuccessful result was due to ULight-Histone $\mathrm{H} 3$ which was not an adequate substrate for Raf- 1 and led to a very low signal/background ratio of 1.5 , not suitable for inhibition studies. This problem was avoided when using the entire MEK-1 protein as an Raf-1 substrate in the LanthaScreen ${ }^{\mathrm{TM}}$ method.

In conclusion, the LanthaScreen ${ }^{\mathrm{TM}}$ Raf- 1 assay appeared to be suitable for routine screening. On the opposite side, 
Table 4 Evaluation of the direct Raf-I and direct MEK-I assays

\begin{tabular}{|c|c|c|c|c|}
\hline \multirow{2}{*}{$\begin{array}{l}\text { Commercial compound } \\
\text { (inhibition type) }\end{array}$} & \multirow{2}{*}{$\begin{array}{l}\text { Published Raf-I } \\
I_{50}(\mathrm{nM})\end{array}$} & \multicolumn{3}{|c|}{ Measured Raf-I IC ${ }_{50}(\mathrm{nM})$} \\
\hline & & PFBA & Lance $^{\circledR}$ Ultra & LanthaScreen $^{\mathrm{TM}}$ \\
\hline \multicolumn{5}{|l|}{ Direct Raf- I } \\
\hline Sorafenib (II) & 6 & $5 \pm 0.5$ & $>50000$ & $9.3 \pm 1.0$ \\
\hline GW5074 (I) & 9 & $9.6 \pm 0.6$ & $>50000$ & $16.2 \pm 1.8$ \\
\hline ZM 336372 (I) & 70 & $80 \pm 8.4$ & $>50000$ & $62 \pm 6.8$ \\
\hline MEK inhibitor II (III) & 34500 & $29500 \pm 943$ & $>50000$ & $22000 \pm 6.0$ \\
\hline \multicolumn{5}{|l|}{ Direct MEK-I } \\
\hline Staurosporine (I) & 4 & $2.7 \pm 0.275$ & $15.6 \pm 2.17$ & n.d. ${ }^{\mathrm{a}}$ \\
\hline MEK inhibitor II (III) & 380 & $4700 \pm 262$ & $>50000$ & n.d. ${ }^{a}$ \\
\hline U0I26 (III) & 530 & $27600 \pm 3670$ & $>50000$ & n.d. ${ }^{a}$ \\
\hline PD98059 (III) & 5000 & $>50000$ & $>50000$ & n.d. ${ }^{a}$ \\
\hline
\end{tabular}

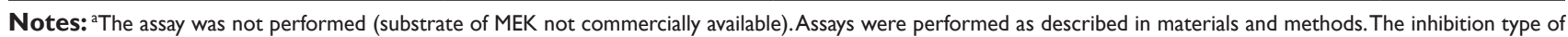
commercial compounds is indicated in brackets: (I) type I inhibitors, which bind exclusively to the ATP-binding site of the kinase; (II) type II inhibitors, which bind to an adjacent allosteric site of the ATP-binding site; (III) type III inhibitors, which bind to an allosteric site remote from the ATP.

in absence of an adequate substrate for Raf-1, the Lance ${ }^{\circledR}$ Ultra direct Raf-1 assay could not be used to detect Raf-1 inhibitors.

\section{Results for the optimization and evaluation of the MEK-I direct assays}

Because labeled ERK-2 for the LanthaScreen ${ }^{\mathrm{TM}}$ assay was not commercially available, only the PFBA and Lance ${ }^{\circledR}$ Ultra MEK-1 direct kinase assays were optimized and evaluated. The same approach was followed as that for the direct Raf-1 kinase assay and the final experimental conditions are indicated in Tables 1 and 2, lines 2.

In order to assess the optimized MEK-1 direct assays, the effects of four commercially available inhibitors were measured. Owing to the available inhibitors, three compounds were allosteric inhibitors of MEK-1: MEK inhibitor II, ${ }^{30}$ U0126, ${ }^{31}$ and PD98059. ${ }^{32}$ The fourth compound was staurosporine, a broad based ATP competitive kinase inhibitor. ${ }^{21}$ As expected, the data revealed (Table 4) that the assays failed to characterize the three allosteric inhibitors U0126, MEK inhibitor II, and PD98059. Indeed, it is known that the allosteric inhibitors are not able to inhibit the active form of MEK-1. ${ }^{32,33}$ In particular, it was demonstrated that PD98059 blocks MEK-1 activation by Raf-1 and not MEK-1 activity. ${ }^{33}$ Probably the LanthaScreen ${ }^{\mathrm{TM}}$ assay would give the same results if it had a better substrate. However, Staurosporine which is an ATP competitive inhibitor was detected as a potent MEK-1 inhibitor and gave an $\mathrm{IC}_{50}$ value of $2.7 \mathrm{nM}$ and $15.7 \mathrm{nM}$ with the PFBA and Lance ${ }^{\circledR}$ Ultra methods, respectively. Because of the discrepancy observed between the two methods and the very weak signal/background ratio of 3 obtained with ULight-p70S6K as an MEK-1 substrate, the Lance ${ }^{\circledR}$ Ultra assay was not sensitive enough to accurately detect MEK-1 inhibitors.

\section{Results for the optimization and evaluation of the ERK-2 direct assays}

The ERK-2 direct kinase assay was optimized for each of the three methods PFBA, Lance ${ }^{\circledR}$ Ultra, and LanthaScreen. ${ }^{\mathrm{TM}}$ As an example, Figure 4 presents the results concerning the optimization of the Lance ${ }^{\circledR}$ Ultra method. The first step was the optimization of the amount of active ERK-2 and ULight-MBP. This was performed by varying the amount of active ERK-2 from 0 to $0.375 \mu \mathrm{M}$ and the amount of ULight-MBP from 0 to $0.4 \mu \mathrm{M}$ in the presence of nonlimiting ATP concentrations (Figure 4a). $187 \mathrm{nM}$ appeared to be the optimal ERK-2 concentration and the ULight-MBP apparent $\mathrm{Km}$ was $0.1 \mu \mathrm{M}$. In these conditions, an apparent $\mathrm{Km}$ value of $0.354 \mu \mathrm{M}$ was obtained for ATP (Figure $4 \mathrm{~b}$ ) and the ERK-2 kinase reaction was linear for up to 45 minutes at room temperature (Figure $4 \mathrm{c}$ ). According to these data, $\mathrm{IC}_{50}$ measurements of ERK-2 inhibitors were performed at the $\mathrm{Km}$ values for both ATP and ULight-MBP for 30 minutes at room temperature (Table 2, line 3). The same optimization steps were performed for the PFBA and the LanthaScreen ${ }^{\mathrm{TM}}$ methods (Tables 1 and 3, lines 3).

To evaluate the optimized ERK-2 direct assays, the effect of two commercially available ATP competitive inhibitors, namely FR180204 ${ }^{34}$ and staurosporine, ${ }^{21}$ were measured. The results are shown in Table 5. The values obtained with 
A

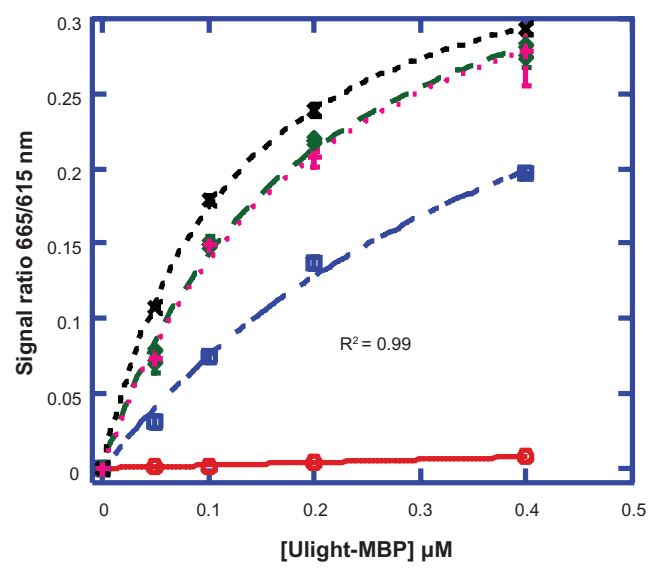

B

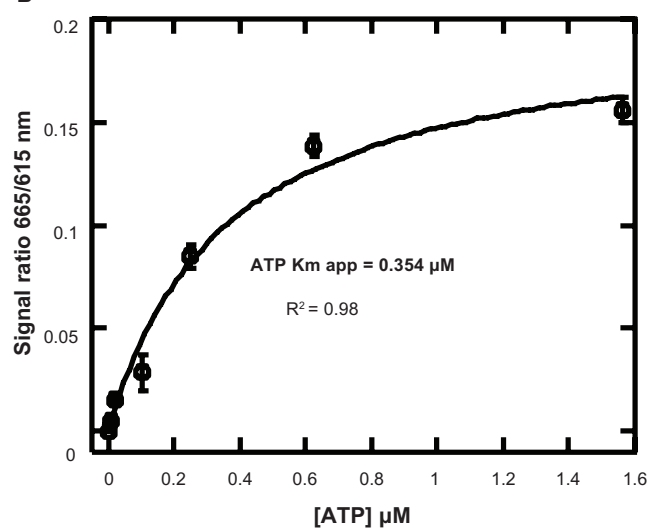

C

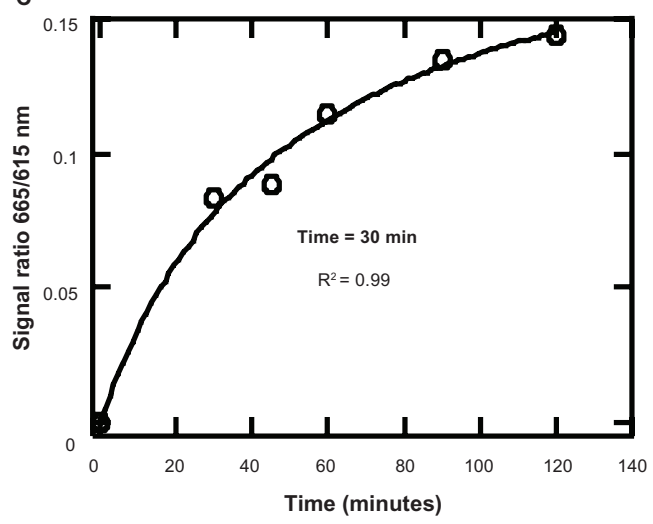

Figure 4 Direct ERK-2 kinase assay with time-resolved fluorescence resonance energy transfer (TR-FRET) Lance ${ }^{\circledR}$ Ultra method. The coefficient of determination $R^{2}$ is shown and error bars represent standard deviation obtained from 3 values. The reactions were terminated after 60 minutes at room temperature, by the addition of $40 \mathrm{mM}$ ethylenediaminetetraacetic acid (EDTA). ULight ${ }^{\mathrm{TM}}$-myelin basic protein (MBP) phosphorylation was detected by the addition of $8 \mathrm{nM}$ Euanti-phospho-MBP. After 20 minutes incubation at RT, the emission fluorescence intensities were recorded at $665 \mathrm{~nm}$ and $615 \mathrm{~nm}$ on a plate reader using an excitation wavelength of $340 \mathrm{~nm}$. The $665 \mathrm{~nm} / 615 \mathrm{~nm}$ ratio was calculated for each well. A) Optimization of active ERK-2 and ULight ${ }^{\text {TM }}$-MBP peptide substrate amounts. Active ERK-2 was titrated from 0 to $0.375 \mu \mathrm{M}$ and ULight ${ }^{\mathrm{TM}}$-MBP from 0 to $0.4 \mu \mathrm{M}$ in the presence of non-limiting $10 \mu \mathrm{M}$ ATP. B) Adenosine triphosphate (ATP) titration. Diluted ATP was added in assay reaction containing $0.187 \mu \mathrm{M}$ ERK-2 and $0.1 \mu \mathrm{M}$ ULight ${ }^{\mathrm{TM}}$-MBP. ATP was varied from 0 to $1.6 \mu \mathrm{M}$. C) Time course of the ERK-2 kinase reaction. The assay was performed using the optimized concentrations of $0.187 \mu \mathrm{M}$ active ERK-2, $0.1 \mu \mathrm{M}$ ULight $^{\mathrm{TM}}$-MBP, and $0.354 \mu \mathrm{M}$ ATP. Reactions were terminated at specific time points by the addition of $40 \mathrm{mM}$ EDTA. the three methods PFBA, Lance ${ }^{\circledR}$ Ultra, and LanthaScreen ${ }^{\mathrm{TM}}$ are coherent between themselves and consistent with $\mathrm{IC}_{50}$ values reported in the literature. Although the two TR-FRET methods were validated for direct ERK-2 kinase assay, the LanthaScreen ${ }^{\mathrm{TM}}$ assay proved to be more sensitive than the Lance ${ }^{\circledR}$ Ultra assay as it used 4 times less enzyme and also less substrate.

\section{Strategy and results for the optimization and evaluation of the double cascade MEK/ERK assays}

Based on the previously determined optimal concentrations of ERK-2 and its substrate (Figure 4a), the amount of active MEK-1 needed to phosphorylate $50 \%$ of the final substrate $\left(\mathrm{EC}_{50}\right)$ was measured. The results are shown in Figure 5; the optimal active MEK-1 concentrations are $7.55 \mathrm{nM}, 2.56$ nM, 1.13 nM for PFBA, Lance ${ }^{\circledR}$ Ultra, and LanthaScreen, ${ }^{\mathrm{TM}}$ respectively. The inhibitory effect of MEK inhibitor II, U0126, PD98059, and staurosporine was tested. In agreement with the results obtained with the direct MEK-1 assays, it was not possible to detect the allosteric inhibitors MEK inhibitor II, U0126, and PD98059 (Table 5). However, a potent inhibition of staurosporine was obtained as indicated by $\mathrm{IC}_{50}$ values of $2.7 \mathrm{nM}$ for PFBA, $1.1 \mathrm{nM}$ for Lance ${ }^{\circledR}$ Ultra, and $1.7 \mathrm{nM}$ for LanthaScreen. ${ }^{\mathrm{TM}}$

In conclusion, the TR-FRET double-cascade assays could be routinely used to study the ATP competitive inhibitors of MEK-1.

\section{Strategy for the optimization and evaluation of the triple cascade Raf/MEK/ERK assays}

The triple cascade assay was optimized by following a multistep approach ${ }^{35}$ using the three methods PFBA, Lance ${ }^{\circledR}$ Ultra, and LanthaScreen. ${ }^{\mathrm{TM}}$ The first step was the double titration of active ERK-2 and its substrate (MBP, ULight-MBP, or GFP-ATF2) in order to determine the optimal concentration of active ERK-2 and the substrate apparent $\mathrm{Km}$ value. The second step was the titration of active MEK-1 in presence of inactive ERK-2 and its substrate to determine the optimal MEK-1 concentration leading to $50 \%$ phosphorylation of the substrate $\left(\mathrm{EC}_{50}\right)$. The third step was the quantification of active Raf-1 in the presence of inactive MEK-1, inactive ERK-2, and the substrate in order to determine the optimal Raf- 1 concentration resulting in $50 \%$ phosphorylation of the substrate. The fourth step was the determination of apparent 
A

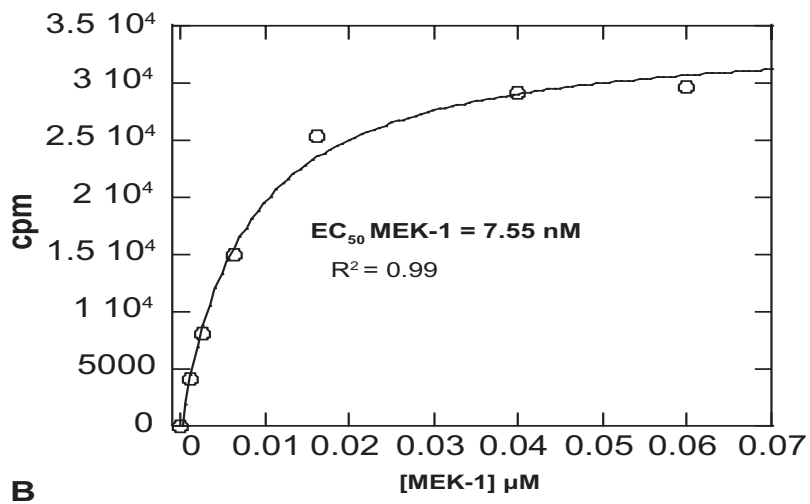

B

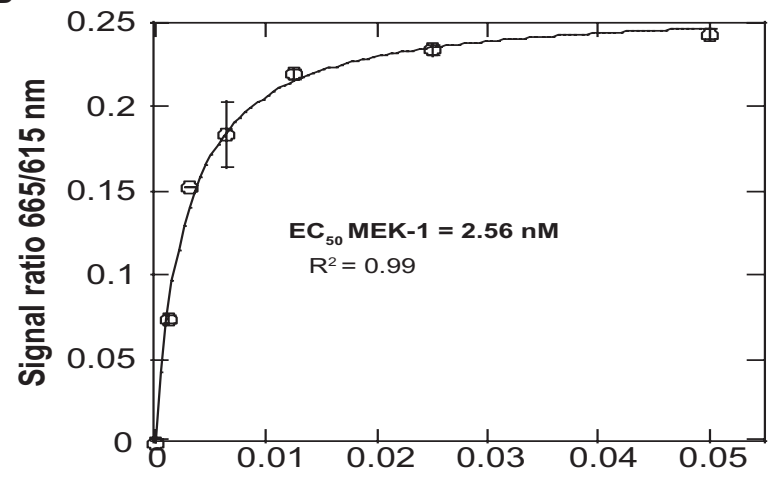

C

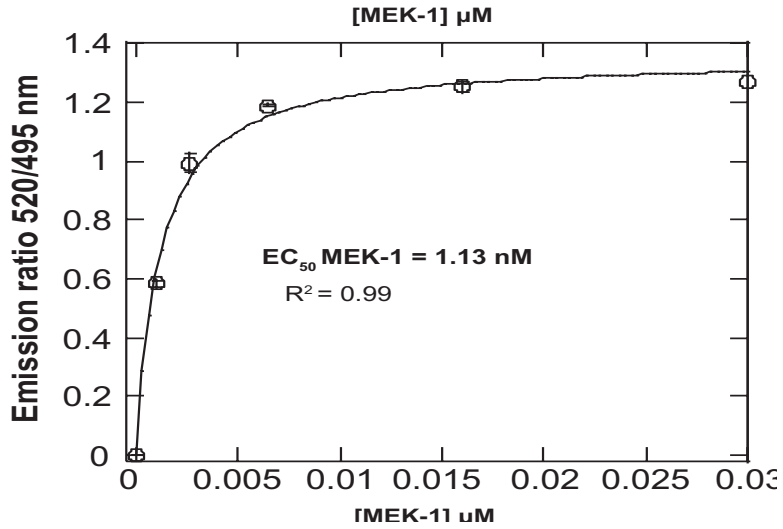

Figure 5 Optimization of active MEK-I concentration for the double cascade MEK/ERK kinase assay. The coefficient of determination $R^{2}$ is shown and error bars represent standard deviation obtained from 3 values. A) phosphocellulose filter binding assay (PFBA) method. Active MEK-I was titrated from 0 to $0.1 \mu \mathrm{M}$ in the presence of $0.05 \mu \mathrm{M}$ inactive ERK-2, I $3 \mu \mathrm{g}$ myelin basic protein (MBP), and a nonlimiting $50 \mu \mathrm{M}$ adenosine triphosphate (ATP) with $0.5 \mu \mathrm{Ci} \gamma-{ }^{32} \mathrm{P}$ ATP, per tube. Reactions were terminated after 20 minutes at $30^{\circ} \mathrm{C}$ by addition of $5 \mu \mathrm{L}$ of $50 \%$ phosphoric acid. The ${ }^{32} \mathrm{P}$ incorporated into the MBP was quantified using a scintillation counter without addition of scintillation cocktail. B) Lance ${ }^{\circledR}$ Ultra method. Active MEK-I was titrated from 0 to $0.3 \mu \mathrm{M}$ in the presence of $0.187 \mu \mathrm{M}$ inactive ERK-2, $0.1 \mu \mathrm{M}$ ULight ${ }^{\mathrm{TM}}$ _MBP, and a nonlimiting $50 \mu$ MATP concentration. Reactions were terminated after 60 minutes at room temperature, by the addition of $40 \mathrm{mM}$ ethylenediaminetetraacetic acid (EDTA). ULight ${ }^{\text {TM }}$-MBP phosphorylation was detected by adding $8 \mathrm{nM}$ Eu-anti-phospho-MBP. After 20 minutes incubation at room temperature, the emission fluorescence intensities were recorded at $665 \mathrm{~nm}$ and $615 \mathrm{~nm}$ on a plate reader using an excitation wavelength of $340 \mathrm{~nm}$. The $665 \mathrm{~nm} / 6 / 5 \mathrm{~nm}$ ratio was calculated for each well. C) LanthaScreen ${ }^{\mathrm{TM}}$ method.Active MEK-I was titrated from 0 to $0.1 \mu \mathrm{M}$ in the presence of $0.05 \mu \mathrm{M}$ inactive ERK-2, $0.04 \mu \mathrm{M}$ GFP-ATF2, and a non-limiting $50 \mu \mathrm{M}$ ATP concentration. Reactions were terminated after 60 minutes at room temperature, by the addition of $40 \mathrm{mM}$ EDTA. GFP-ATF2 phosphorylation was detected by the addition of $8 \mathrm{nM}$ Tb-anti-phospho-ATF2. After 60 minutes incubation at room temperature, emission intensities were recorded at $445 \mathrm{~nm}$ and $520 \mathrm{~nm}$ wavelengths on a plate reader using an excitation wavelength of $340 \mathrm{~nm}$. The $445 \mathrm{~nm} / 520 \mathrm{~nm}$ ratio was calculated for each well.
$\mathrm{Km}$ for ATP. In the fifth step, the triple cascade time course was monitored in the presence of optimized concentrations for active Raf-1, inactive MEK-1, inactive ERK-2, and apparent $\mathrm{Km}$ concentrations for ERK-2 substrate and ATP, in order to select an incubation time in the linear reaction range. All these optimization steps were essential to ensure that assay sensitivity was compatible with detection of Raf, MEK, and/or ERK inhibitors.

\section{Results for the optimization and evaluation of the triple cascade Raf/MEK/ERK assays}

As an example, the optimization of the Lance ${ }^{\circledR}$ Ultra triple cascade Raf/MEK/ERK kinase assay is illustrated in Figure 6. It is noticeable that the first and second optimization steps were previously performed and are described in Figure 4a and Figure $5 \mathrm{~b}$ respectively. The third step was the optimization of the active Raf-1 concentration (Figure 6a). It was performed by varying the Raf- 1 concentration from 0 to $10 \mathrm{ng} /$ well $(15.4 \mathrm{nM})$ in the presence of previously optimized concentrations for inactive MEK-1 $(2.56 \mathrm{nM})$, inactive ERK$2(0.187 \mu \mathrm{M})$, ULight-MBP $(0.1 \mu \mathrm{M})$, and nonlimiting ATP concentration. A Raf- $1 \mathrm{EC}_{50}$ value of $0.615 \mathrm{nM}$ was obtained. These enzymes and substrate concentrations were selected to determine an apparent Km ATP value of $5 \mu \mathrm{M}$ (Figure 6b). The triple cascade assay was linear for up to 60 minutes at room temperature (Figure 6c). Based on these results, the $\mathrm{IC}_{50}$ measurements of Raf/MEK/ERK inhibitors were performed with the Lance ${ }^{\circledR}$ Ultra method in final experimental conditions indicated in Table 2. The same optimization steps were performed for the PFBA and the LanthaScreen ${ }^{\mathrm{TM}}$ methods (Tables 1 and 3).

For evaluation of the triple cascade Raf/MEK/ERK kinase assays, three Raf-1 inhibitors (sorafenib, GW5074, ZM336372), three MEK inhibitors (MEK inhibitor II, U0126, PD98059), one ERK inhibitor (FR180204), and the large broad inhibitor Staurosporine were used. The results are shown in Table 6 . The measured $\mathrm{IC}_{50}$ values were coherent with the reported $\mathrm{IC}_{50}$ values for the three methods PFBA, Lance ${ }^{\circledR}$ Ultra, and LanthaScreen. ${ }^{\mathrm{TM}}$ However, a 7-fold potency increase for ZM336372 and a 5-fold potency decrease for MEK inhibitor II were observed with the LanthaScreen ${ }^{\mathrm{TM}}$ method. One explanation is that these results could be due to interference between inhibitors and the bulky GFP part (238 amino acids) of the GFP-ATF2 substrate, leading to an increase or decrease of the observed $\mathrm{IC}_{50}$ values. On the contrary, no disruption of signal fluorescence was 
Table 5 Evaluation of the direct ERK-2 and double cascade MEK/ERK assays

\begin{tabular}{|c|c|c|c|c|}
\hline \multirow{2}{*}{$\begin{array}{l}\text { Commercial compound } \\
\text { (inhibition type) }\end{array}$} & \multirow{2}{*}{$\begin{array}{l}\text { Published } \\
I_{50}(\mathrm{nM})\end{array}$} & \multicolumn{3}{|c|}{ Measured IC $C_{50}(\mathrm{nM})$} \\
\hline & & PFBA & Lance ${ }^{\circledR}$ Ultra & LanthaScreen ${ }^{T I}$ \\
\hline \multicolumn{5}{|l|}{ Direct ERK2 } \\
\hline FRI 80204 (I) & 330 & $310 \pm 33.1$ & $268 \pm 44.4$ & $259 \pm 27.9$ \\
\hline Staurosporine (I) & 4400 & $1900 \pm 194$ & $1000 \pm 23.2$ & $2100 \pm 273$ \\
\hline \multicolumn{5}{|l|}{ MEK/ERK } \\
\hline Staurosporine (I) & 4 & $2.70 \pm 0.27$ & $1.7 \pm 0.29$ & $1.1 \pm 0.19$ \\
\hline MEK inhibitor II (III) & 380 & $7000 \pm 0.289$ & $4600 \pm 59.5$ & $8700 \pm 747.9$ \\
\hline U0I26 (III) & 530 & $33100 \pm 3.67$ & $4500 \pm 206.6$ & $3800 \pm 825.9$ \\
\hline PD98059 (III) & 5000 & $>50000$ & $>50000$ & $>50000$ \\
\hline
\end{tabular}

Notes: Assays were performed as described in Materials and methods. The inhibition type of commercial compounds is indicated in brackets: (I) type I inhibitors, which bind exclusively to the ATP-binding site of the kinase; (III) type III inhibitors, which bind to an allosteric site remote from the ATP.

observed with the Lance ${ }^{\circledR}$ Ultra technology which uses the small ULight acceptor dye.

Interestingly, using the triple cascade assays, the expected $\mathrm{IC}_{50}$ values were obtained for the three allosteric MEK-1 inhibitors U0126, MEK inhibitor II, and PD98059. These results agree with the previous observation that U0126, MEK inhibitor II, and PD98059 display affinity toward the inactive form of MEK-1 (used in the triple cascade assays) and not toward the MEK-1 active form (used in the direct MEK-1 and double cascade assays). All these data are in agreement with the fact that the three inhibitors act by preventing MEK-1 phosphorylation by Raf-1 and not by inhibiting MEK-1 activity. ${ }^{33}$

In conclusion, the triple cascade $\mathrm{Raf} / \mathrm{MEK} / \mathrm{ERK}$ is suitable to detect the inhibitors of each kinase of the cascade. In particular, it is the most adapted test to detect allosteric as well as ATP competitive inhibitors of MEK-1. The LanthaScreen ${ }^{\mathrm{TM}}$ assay was more sensitive than the Lance ${ }^{\circledR}$ Ultra assay but it was liable to interfere with some compounds. Thus, the Lance ${ }^{\circledR}$ Ultra method was chosen to test routinely the newly synthesized potential MEK-1 inhibitors.

\section{Assessment of the robustness and performance of the assays}

In high-throughput screening, the robustness and performance of kinase assays are currently evaluated by determining the $Z^{\prime}$-factor value. The equation and the meaning of the $Z^{\prime}$-factor was reported by Zhang et al. ${ }^{26}$ Its value is calculated from four parameters that are the averages and standard deviations of both the positive and negative controls. All the $Z^{\prime}$ values are indicated in Table 7 : between 0.5 and 1 they are evidence of the robustness and reproducibility of the optimized assays and ensure that the methods are adequate to study inhibitors on the Raf/MEK/ERK cascade. Except for the Lance ${ }^{\circledR}$ Ultra direct Raf-1 and MEK-1 assays (for which no adequate substrates were available) and the LanthaScreen $^{\mathrm{TM}}$ direct MEK-1 assay (MEK-1 substrate was not commercially available), all the other assays displayed a high level of robustness and reproducibility.

\section{Screening of synthesized inhibitors}

Several families of new synthesized inhibitors were tested. Two of them displayed interesting inhibitory properties and constituted leads for the synthesis of new products. The detailed synthesis of the products and their effects on cells and animals will be described elsewhere. The chemical formula and the Raf-1 inhibitory effect for one of the compounds, Fs289, are shown in Figure 7. The $\mathrm{IC}_{50}$ values were similar with the LanthaScreen ${ }^{\mathrm{TM}}$ (Figure 7b) and PFBA (Figure 7c) methods, either for direct Raf-1 or triple cascade (Figure 7d) assays, indicating that Fs289 acts specifically on Raf-1 and does not interfere with the TR-FRET acceptor dyes.

\section{Raf/MEK/ERK inhibition by PEBP/RKIP}

In parallel with the chemical screening of the compounds, the developed assays were tested for their ability to measure the effect of PEBP/RKIP, a natural inhibitor of the Raf/MEK/ERK pathway, known to act by direct interaction with Raf, MEK, and ERK. ${ }^{23}$ In human beings, RKIP/PEBP is one of the few gene products with a demonstrated metastasis suppressor activity. ${ }^{36}$ Furthermore, PEBP/RKIP was also found to sensitize tumor cells to chemotherapy ${ }^{37}$ and immunotherapy. ${ }^{38}$ To date, only one type of method has been described to measure the effect of PEBP/RKIP in vitro on purified enzymes. ${ }^{18,23}$ It consists of detecting the ${ }^{32} \mathrm{P}$ incorporated into the substrate during the kinase reaction by gel electrophoresis autoradiography. The inhibitory effect of 
A

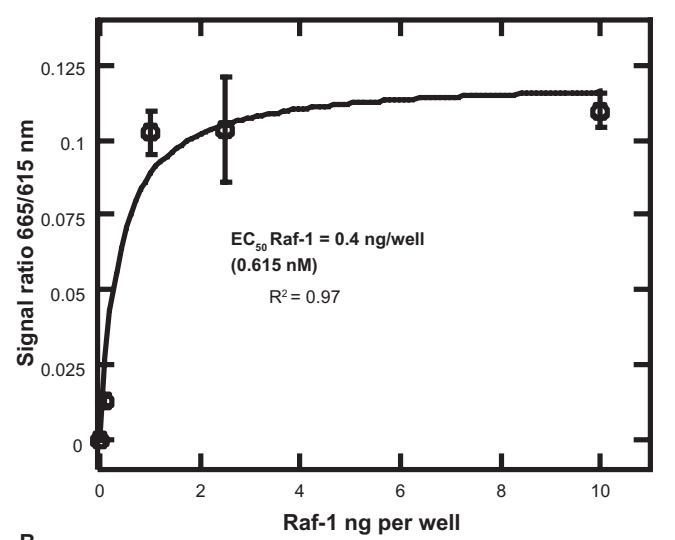

B

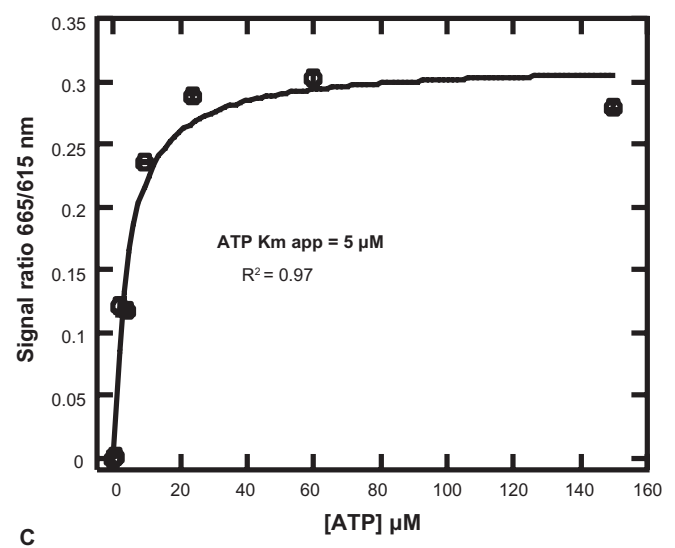

C

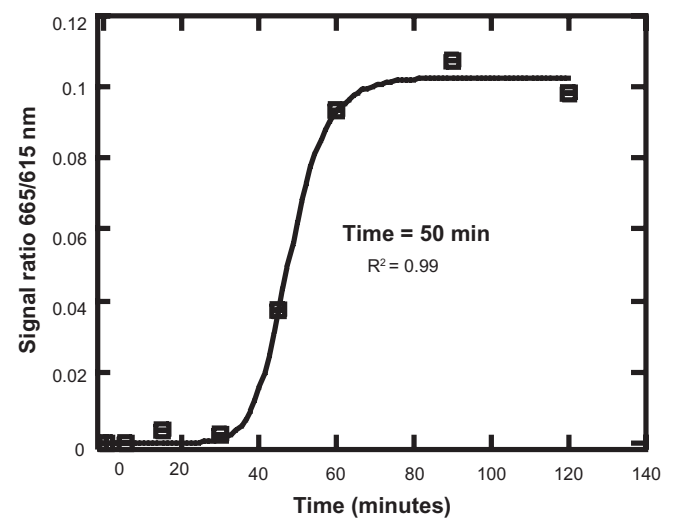

Figure 6 Triple cascade Raf/MEK/ERK kinase assay with time-resolved fluorescence resonance energy transfer (TR-FRET) Lance ${ }^{\circledast}$ Ultra method. The coefficient of determination $R^{2}$ is shown and error bars represent standard deviation obtained from 3 values. The reactions were stopped after 60 minutes at room temperature by the addition of $40 \mathrm{mM}$ ethylenediaminetetraacetic acid (EDTA). ULight ${ }^{\mathrm{TM}}{ }_{-} \mathrm{MBP}$ (myelin basic protein) peptide phosphorylation was detected by the addition of 8 nM Eu-anti-phospho_MBP. After 20 minutes incubation at room temperature, the emission fluorescence intensities were recorded at $665 \mathrm{~nm}$ and $615 \mathrm{~nm}$ on a plate reader using an excitation wavelength of $340 \mathrm{~nm}$. The $665 \mathrm{~nm} / 6 / 5 \mathrm{~nm}$ ratio was calculated for each well. A) Optimization of active Raf-I concentration. Active Raf-I concentration was varied from 0 to $10 \mathrm{ng} /$ well $(15.4 \mathrm{nM})$ in the presence of $2.56 \mathrm{nM}$ inactive MEK-I, $0.187 \mu \mathrm{M}$ inactive ERK-2, $0.1 \mu \mathrm{M}$ ULight ${ }^{\mathrm{m}}$-MBP, and $50 \mu \mathrm{M}$ adenosine triphosphate (ATP). B) ATP titration. Diluted ATP was added in assay reaction containing $615 \mathrm{nM}$ active Raf-I, $2.56 \mathrm{nM}$ inactive MEK-I, $0.187 \mu \mathrm{M}$ inactive ERK-2, and $0.1 \mu \mathrm{M}$ ULight ${ }^{\mathrm{TM}}$-MBP.ATP concentration was varied from 0 to $150 \mu \mathrm{M}$. C) Time course of the Raf/MEK/ERK kinase reaction. The assay was performed using the optimized concentrations of $615 \mathrm{nM}$ active Raf-I, $2.56 \mathrm{nM}$ inactive MEK-I, $0.187 \mu \mathrm{M}$ inactive ERK-2, $0.1 \mu \mathrm{M}$ Ulight ${ }^{\mathrm{TM}}$ _MBP, and $5 \mu \mathrm{M}$ ATP. Reactions were terminated at specific time points by the addition of $40 \mathrm{mM}$ EDTA.
PEBP/RKIP was measured with all the optimized assays described above (Figure 8). Since PEBP/RKIP was dissolved in the appropriate kinase buffer at $1 \mathrm{mg} / \mathrm{mL}(50 \mu \mathrm{M})$, the maximal concentration of PEBP/RKIP used per assay was $25 \mu \mathrm{M}$. This stoichiometric ratio between kinases and PEBP/ RKIP is similar to that found in several cell lineages. ${ }^{39}$ The curves obtained for the PFBA method (Figure 8a) show that the strongest inhibitor effect of PEBP/RKIP is observed for the triple cascade Raf/MEK/ERK assay (93\% inhibition at $25 \mu \mathrm{M}$ PEBP/RKIP). The inhibitory effect decreases on the double cascade MEK/ERK with $74 \%$ inhibition. It decreases again for the direct assays: $60 \%$ for the MEK-1 inhibition, $56 \%$ for ERK-2 inhibition, and $43 \%$ for Raf-1 inhibition. PEBP/RKIP seems to be slightly less inhibitory for Raf-1 than for MEK and ERK. This result agrees with the previous observation that Raf activation weakens its affinity towards PEBP/RKIP. ${ }^{23}$ Moreover it is noticeable that commercially available Raf-1 is always truncated (306-end) because its catalytic domain is stable, whereas the N-terminal domain is unstable. It is likely that the efficiency of PEBP/RKIP on the complete Raf-1 (1-end) is different to the observed inhibition with the truncated enzyme.

Results obtained with the Lance ${ }^{\circledR}$ Ultra and Lantha Screen $^{\mathrm{TM}}$ methods (Figure $8 \mathrm{~b}$ ) are in complete agreement with the PFBA data. The strong inhibitory effect observed on the triple cascade Raf/MEK/ERK is probably due to the fact that PEBP/RKIP acts both on the inactive and the active forms of the three kinases. It was previously shown that PEBP/RKIP acts on Raf- 1 activity and also on Raf- 1 activation by Ras. ${ }^{22}$ The results presented here strongly suggest that the mechanism of action of PEBP/RKIP leads to the inhibition of the activity and also the activation of each kinase in the cascade.

\section{Discussion}

\section{Evaluation of the PFBA, Lance ${ }^{\circledR}$ Ultra, and LanthaScreen ${ }^{\mathrm{TM}}$ assays}

Several factors to be considered when developing a kinase assay include the assay technology, format, and choice of substrate. However, despite numerous options, there is no perfect assay configuration that suits all needs and ultimately, the application of the assay is the most important factor that will dictate the direction of assay development. ${ }^{40}$ Considering the interest of the Raf/MEK/ERK pathway in cancer, several companies continuously develop and supply new technologies and reagents dedicated to identifying inhibitors that are expected to become drugs against cancer. Developing a valid and robust in vitro assay is critical for inhibitor screening. 
Table 6 Evaluation of the triple cascade Raf/MEK/ERK assay

\begin{tabular}{|c|c|c|c|c|c|}
\hline & \multirow{2}{*}{$\begin{array}{l}\text { Commercial } \\
\text { compound } \\
\text { (inhibition type) }\end{array}$} & \multirow{2}{*}{$\begin{array}{l}\text { Published } \\
I_{50}(n M)\end{array}$} & \multicolumn{3}{|c|}{ Measured IC $\mathrm{C}_{50}(\mathrm{nM})$} \\
\hline & & & PFBA & Lance ${ }^{\circledR}$ Ultra & LanthaScreen ${ }^{\mathrm{TM}}$ \\
\hline \multirow[t]{3}{*}{ Raf inhibitors } & Sorafenib (II) & 6 & $7 \pm 0.6$ & $5 \pm 0.3$ & $5.6 \pm 0.071$ \\
\hline & GW5074 (I) & 9 & $3.2 \pm 0.3$ & $8.3 \pm 2.4$ & $10.2 \pm 2.3$ \\
\hline & ZM336372 (I) & 70 & $49 \pm 12.3$ & $63.5 \pm 8.7$ & $9 \pm 0.94$ \\
\hline \multirow[t]{3}{*}{ MEK inhibitors } & Mek inhibitor II (III) & 380 & $694 \pm 160$ & $353 \pm 64.3$ & $2000 \pm 428$ \\
\hline & U0I26 (III) & 530 & $285 \pm 40$ & $800 \pm 81.1$ & $125 \pm 11.5$ \\
\hline & PD98059 (III) & 5000 & $5000 \pm 637$ & $2700 \pm 704$ & $000 \pm 152$ \\
\hline ERK inhibitor & FRI80204 (I) & 330 & $146 \pm 61.1$ & $133 \pm 26.7$ & $130 \pm 20$ \\
\hline Other & Staurosporine (I) & 63 & $\mathrm{I} .3 \pm 0.36$ & $2.6 \pm 0.19$ & $\mathrm{I} . \mathrm{I} \pm 0.2$ \\
\hline
\end{tabular}

Notes: Assays were performed as described in materials and methods. The inhibition type of commercial compounds is indicated in brackets: (I) type I inhibitors, which bind exclusively to the ATP-binding site of the kinase; (II) type II inhibitors, which bind to an adjacent allosteric site of the ATP-binding site; (III) type III inhibitors, which bind to an allosteric site remote from the ATP.

The investigator therefore needs to test the most recent methodologies and compare them with classical techniques. In this perspective, we optimized, evaluated, and compared two recent TR-FRET methods by using the PFBA technique and literature data as references.

Recently, several authors have described assays using radioactive, FRET or TR-FRET methods to measure Raf/MEK/ERK activity. ${ }^{21,40,41}$ However, the technologies used were different from those that are described here and the efficiencies of Lance ${ }^{\circledR}$ Ultra and LanthaScreen ${ }^{\mathrm{TM}}$ to detect various types of Raf/MEK/ERK inhibitors were not compared. The analysis of our results revealed several main points. Our results indicated that the peptide-substrates used to test Raf-1 and MEK-1 activities in the Lance ${ }^{\circledR}$ Ultra assays were not suitable to detect inhibitory effects. This could be related to the very poor ratio signal/background observed with these particular substrates. The inhibitors of MEK-1 could not be detected with the TR-FRET direct MEK-1 assays. In this case, the double cascade MEK/ERK is suitable to study the ATP competitive inhibitors of MEK-1, and triple cascade Raf/MEK/ERK could be useful to detect the allosteric inhibitors of MEK-1. Another point is that the triple cascade assays revealed wrong $\mathrm{IC}_{50}$ values for ZM336372 and MEK inhibitor
II with the LanthaScreen ${ }^{\mathrm{TM}}$ assay (Table 6). One explanation is the possible interaction of the inhibitors with the bulky GFP-ATF2 substrate leading to a modification of the fluorescence signal. Therefore, these results strongly suggest that the use of bulky acceptor dyes may present drawbacks for measuring the inhibitory effect of some compounds in TR-FRET assays.

\section{PEBP/RKIP is essentially an inhibitor of the whole cascade}

To date, only tests based on radioactivity and gel electrophoresis have been described to measure the inhibitory effect of PEBP/RKIP on the Raf/MEK/ERK pathway. In this paper, we used an easier and faster method to test in vitro the effect of PEBP/RKIP on separate purified kinases, double cascade MEK/ERK, and triple Raf/MEK/ERK cascade. Our results (Figure 8) showed that PEBP/RKIP displays partial inhibitory effect on isolated kinases, since it inhibits ERK-2 (56\% inhibition), MEK (60\% inhibition), and Raf-1 (43\% inhibition) at a concentration of $25 \mu \mathrm{M}$ per assay. More interestingly, our data revealed that PEBP/RKIP is more efficient on the whole cascade (95\%). These results are in complete agreement with the previous

Table 7 Z' factors calculated for each assay

\begin{tabular}{|c|c|c|c|}
\hline Assay & PFBA & Lance ${ }^{\circledR}$ Ultra & LanthaScreen $^{\mathrm{TM}}$ \\
\hline Direct Raf-I & 0.88 & n.d. ${ }^{a}$ & 0.83 \\
\hline Direct MEK-I & 0.77 & n.d. ${ }^{b}$ & n.d.c \\
\hline ERK-2 & 0.81 & 0.86 & 0.82 \\
\hline MEK/ERK & 0.81 & 0.84 & 0.76 \\
\hline Raf/MEK/ERK & 0.88 & 0.86 & 0.87 \\
\hline
\end{tabular}

Notes: The $Z^{\prime}$ factors were calculated as $\left.Z^{\prime}=1-\left[\left(3 \sigma_{c^{+}}+3 \sigma_{c-}\right) /\left(\mu c^{+}-\mu c^{-}\right)\right]\right)$where $\sigma$ is the standard deviation and $\mu$ is the mean of the positive $\left(c^{+}\right)$or the negative $\left(c^{-}\right)$ controls; n.d. ${ }^{a}$, not determined because Ulight-Histone $\mathrm{H} 3$ was not an adequate substrate for Raf-I (signal/background = I.5); n.d. ${ }^{b}$, not determined because Ulight-p70S6K was not an adequate substrate for MEK-I (signal/background = 3); n.d. ${ }^{c}$, the assay was not performed because no substrate of MEK-I was commercially available. 
A<smiles>Nc1cccc(C(=O)n2ccc3nc(Nc4ccc(Cl)c(C(F)(F)F)c4)ccc32)c1</smiles>

C

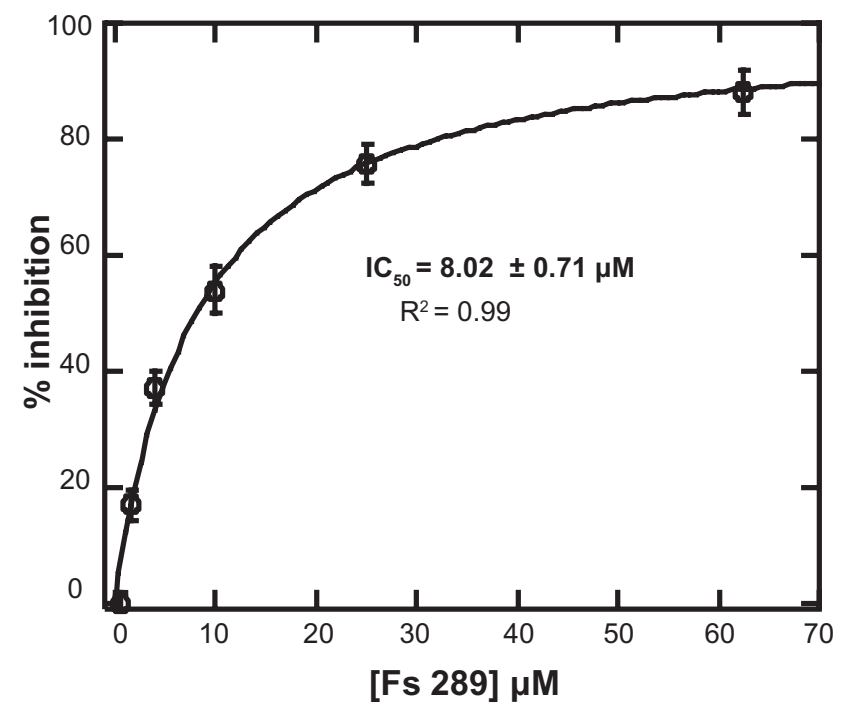

B

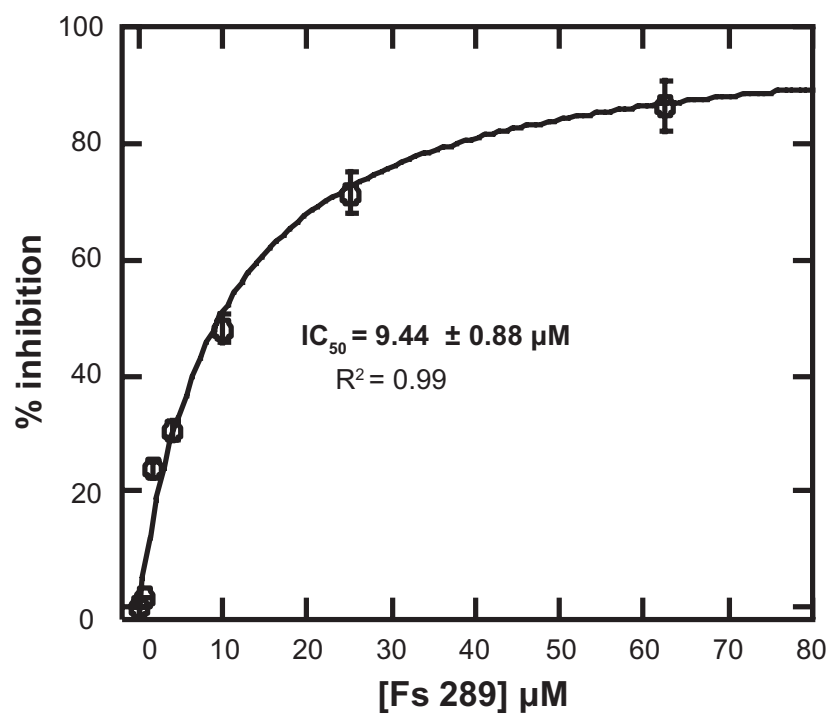

D

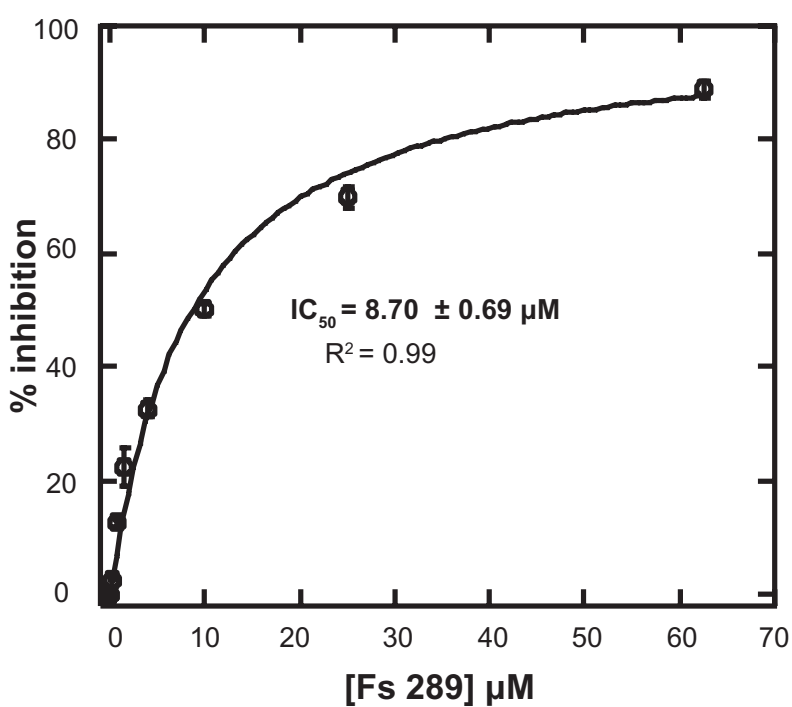

Figure 7 Fs289 inhibitory effect. A) Formula of the synthesized product. B) LanthaScreen ${ }^{T M}$ Raf-I direct assay. C) phosphocellulose filter binding assay (PFBA) Raf-I direct assay. D) Lance ${ }^{\circledR}$ Ultra triple cascade Raf/MEK/ERK assay. The three assays gave comparable results.

description that PEBP/RKIP can form ternary complexes with Raf-1, MEK, and ERK. ${ }^{23}$ In complement to data previously published, ${ }^{22}$ our results indicated that PEBP/ RKIP can significantly inhibit in vitro all the enzymes of the Raf/MEK/ERK cascade.

\section{Conclusion}

The series of assays described in this paper target the Raf/MEK/ERK cascade as well as the deconvolution of the inhibitory activity. All the described assays were validated with at least one of the two tested TR-FRET methods, except the direct MEK-1 assays, due to the absence of an adequate substrate for MEK-1. Concerning the direct Raf-1 assay, only the LanthaScreen ${ }^{\mathrm{TM}}$ method was validated.

In our laboratory we are currently performing the whole Raf/MEK/ERK cascade assay to highlight inhibitors acting on one or several kinases of the cascade. If it appears that a newly synthesized compound displays an inhibitory effect on the whole cascade, then its action on each of the kinases is evaluated. The triple cascade Raf/MEK/ERK cascade is also used to detect the ATP competitive as well as the allosteric inhibitors of MEK-1. The double cascade MEK/ERK could be useful to study the ATP competitive inhibitors of MEK-1. Considering the interferences observed between the LanthaScreen ${ }^{\mathrm{TM}}$ acceptor dyes and some chemical 
A

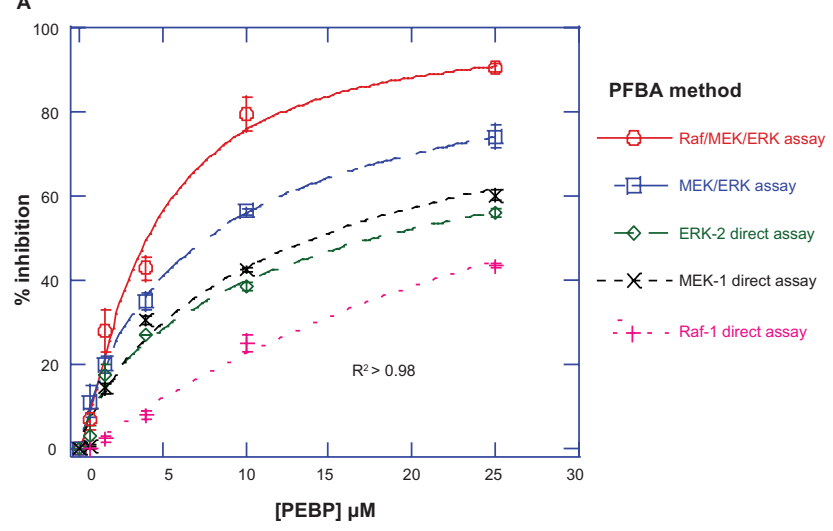

B

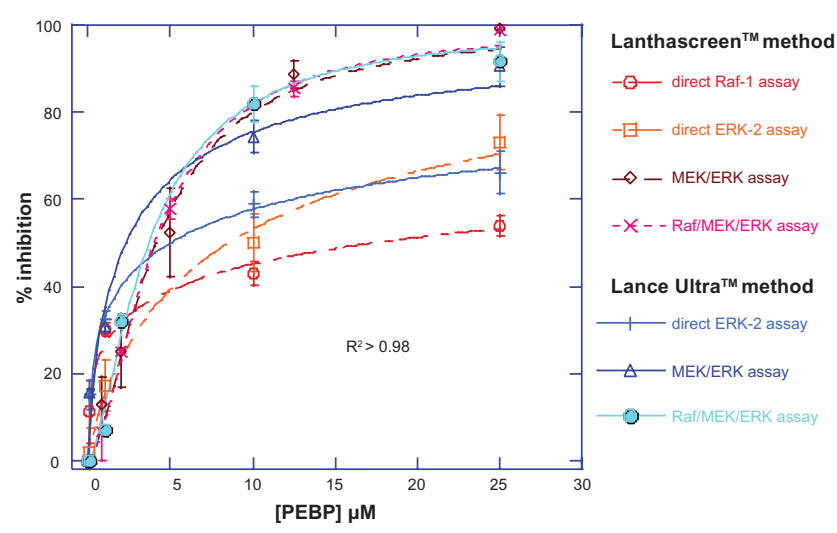

Figure 8 Phosphatidyl ethanolamine binding protein (PEBP)/Raf kinase inhibitor protein (RKIP) inhibitory effect. The coefficient of determination $R^{2}$ is shown and error bars represent standard deviation from $n=6$ values. PEBP/RKIP was varied from 0 to $25 \mu \mathrm{M}$. A) Phosphocellulose filter-binding assay (PFBA) assays. PEBP/RKIP was incubated for 20 minutes at room temperature with the enzyme(s), the reaction was initiated by addition of adenosine triphosphate (ATP) and was terminated after 20 minutes (except for direct MEK-I and direct ERK2, 10 minutes) at $30^{\circ} \mathrm{C}$ The ${ }^{32} \mathrm{P}$ incorporated in the substrate was quantified using a scintillation counter. All the assays were performed according to the detailed conditions described in Table I. B) LanthaScreen ${ }^{\mathrm{TM}}$ and Lance ${ }^{\circledR}$ Ultra assays. PEBP/RKIP was incubated for 20 minutes at room temperature with the enzyme(s), the reaction was initiated by addition of ATP and substrate (fluorescein-MEK-I or GFP-ATF2 for LanthaScreen ${ }^{\text {TM }}$ method and ULight ${ }^{\mathrm{TM}}$-myelin basic protein (MBP) for Lance ${ }^{\circledR}$ Ultra method). After incubation at room temperature, reaction was stopped by $40 \mathrm{mM}$ ethylenediaminetetraacetic acid (EDTA). Phosphorylated substrate was detected by addition of $8 \mathrm{nM}$ of specific antibody (Tb-anti-phospho-fluorescein-MEK-I orTb-anti-phospho-ATF2 for LanthaScreen $^{T M}$ method and Eu-anti-phospho-MBP for Lance ${ }^{\circledR}$ Ultra method).After 20 minutes reaction at room temperature, emission fluorescence intensities were recorded on a plate reader using an excitation wavelength of $340 \mathrm{~nm}$. For LanthaScreen ${ }^{\text {TM }}$ method, emission wavelengths were $445 \mathrm{~nm}$ and $520 \mathrm{~nm}$, the $445 \mathrm{~nm} / 520 \mathrm{~nm}$ ratio was calculated for each well. For Lance ${ }^{\circledR}$ Ultra method, emission wavelengths were $665 \mathrm{~nm}$ and $615 \mathrm{~nm}$ and the $665 \mathrm{~nm} / 615 \mathrm{~nm}$ ratio was calculated.All the assays were performed according to the detailed conditions described in Tables 2 and 3 . In absence of suitable commercially available substrates for Raf-I and MEK-I, the corresponding Lance ${ }^{\circledR}$ Ultra assays were not performed. Because no MEK-I substrate was available, the LanthaScreen ${ }^{\mathrm{TM}}$ direct MEK-I assay was not performed.

compounds, the Lance ${ }^{\circledR}$ Ultra triple cascade assay is routinely used as a first-line test. To our knowledge, it is the first time that Lance ${ }^{\circledR}$ Ultra technology has been routinely applied to test the inhibition of the whole Raf/MEK/ERK cascade. In the other cases (individual kinases or double cascade MEK/ERK assays), because the LanthaScreen ${ }^{\mathrm{TM}}$ method is less enzyme consuming than the Lance ${ }^{\circledR}$ Ultra, it is currently used if no interference occurs with the given inhibitor.

\section{Acknowledgments}

This work was funded by the Centre National de la Recherche Scientifique (CNRS), the University of Orléans, la Ligue contre le cancer Comités du Loiret, Ille-et-Vilaine et Vendée, le Cancéropôle du Grand Ouest, la Région Centre and the Institut National du Cancer (PhD fellowship to F. Saab).

We wish to thank G. Gabant, mass spectrometry platform (Orléans, CBM), for analyzing kinases and PEBP/RKIP samples.

\section{Disclosures}

The authors report no conflicts of interest in this work.

\section{References}

1. Roberts PJ, Der CJ. Targeting the Raf-Mek-Erk mitogen-activated protein kinase cascade for the treatment of cancer. Oncogene. 2007;26:3291-3310.

2. Sebolt-Leopold JS. Advances in the development of cancer therapeutics directed against the Ras-mitogen-activated protein kinase pathway. Clin Cancer Res. 2008;14:3651-3656.

3. Khono M, Pouyssegur J. Pharmacological inhibitors of ERK signaling pathway: application as anticancer drugs. Prog Cell Cycle Res. 2003;5:219-224.

4. Sebolt-Leopold JS, Herrera R. Targeting the mitogen-activated protein kinase cascade to treat cancer. Nat Rev Cancer. 2004;4: 937-947.

5. Kolch W. Meaningful relationships: the regulation of the Ras/Raf/ MEK/ERK pathway by protein interactions. Biochem J. 2000;351: 289-305.

6. Downward J. Targeting RAS signaling pathways in cancer therapy. Nat Rev Cancer. 2003;3:11-22.

7. Scharovsky OG, Rozados VR, Gervasoni SI, Matar P. Inhibition of Ras oncogene: a novel approach to antineoplastic therapy. J Biomed Sci. 2000;7:292-298.

8. Yoon S, Seger R. The extracellular signal-regulated kinase: multiple substrates regulate diverse cellular functions. Growth Factors. 2006;24:21-44.

9. Khazak V, Astsaturov I, Serebriiskii IG, Golernis EA. Selective Raf inhibition in cancer therapy. Expert Opin Ther Targets. 2007;11: 1587-1609.

10. Sridhar SS, Hedley D, Siu LL. Raf kinase as a target for anticancer therapeutics. Mol Cancer Ther. 2005;4:677-685.

11. McCubrey JA, Milella M, Tafuri A, et al. Targeting the Raf/MEK/ERK pathway with small-molecule inhibitors. Curr Opin Investig Drugs. 2008;9:614-630.

12. Yeh TC, Marsh V, Bernat BA, et al. Biological characterization of ARRY142886 (AZD6244), a potent, highly selective mitogen-activated protein kinase kinase 1/2 inhibitor. Clin Cancer Res. 2007;13:1576-1583.

13. Rinehart J, Ndjel AA, Lorusso PM, et al. Multicenter phase II study of the oral MEK inhibitor, CI-1040, in patients with advanced nonsmall-cell lung, breast, colon, and pancreatic cancer. J Clin Oncol. 2004;22:4456-4462.

14. LoRusso PA, Krishnamurthi S, Rinehart JR, et al. A phase 1-2 clinical study of a second generation oral MEK inhibitor, PD 0325901 in patients with advanced cancer. J Clin Oncol [abstract]. 2005;23 (No165):3011. 
15. Menon SS, Whitfield LR, Sadis S, et al. Pharmacokinetics (PK) and pharmacodynamics (PD) of PD 0325901, a second generation MEK inhibitor after multiple oral doses of PD 0325901 to advanced cancer patients. J Clin Oncol [abstract]. 2005;23(No168):3066.

16. von Ahsen O, Bömer U. High-throughput screening for kinase inhibitors. Chem Bio Chem. 2005;6:481-490.

17. Ishida A, Kameshita I, Sueyoshi N, Taniguchi T, Shigeri Y. Recent advances in technologies for analyzing protein kinases. J Pharmacol Sci. 2007;103:5-11.

18. Alessi DR, Cohen P, Ashworth A, et al. Assay and expression of mitogen-activated protein kinase, MAP kinase kinase, and Raf. Methods Enzymol. 1995;255:279-290.

19. Application note: development and optimization of kinase assays using new LANCE Ultra TR-FRET Reagents: http://las.perkinelmer. com/content/applicationnotes/app_developmentoptimizationkinasela ceultratrfretreagents.pdf

20. Riddle SM, Vedvik KL, Hanson GT, Vogel KW. Time-resolved fluorescence resonance energy transfer kinase assays using physiological protein substrates: applications of terbium-fluorescein and terbiumgreen fluorescent protein fluorescence resonance energy transfer pairs. Anal Biochem. 2006;356:108-116.

21. Kupcho KR, Bruinsma R, Hallis TM, et al. Fluorescent cascade and direct assays for characterization of Raf signaling pathway inhibitors. Curr Chem Genom. 2008;1:43-53.

22. Yeung K, Seitz T, Li S, et al. Suppression of Raf-1 kinase activity and MAP kinase signaling by RKIP. Nature. 1999;401:173-177.

23. Yeung K, Janosch P, Mcferran B, et al. Mechanism of suppression of the Raf/MEK/extracellular signal-regulated kinase pathway by the Raf kinase inhibitor protein. Mol Cell Biol. 2000;20:3079-3085.

24. Park S, Rath O, Beach S, et al. Regulation of RKIP binding to the N-region of the Raf-1 kinase. FEBS Lett. 2006;580:6405-6412.

25. Atmanene C, Laux A, Glattard E, et al. Characterization of human and bovine phosphatidylethanolamine-binding Protein (PEBP/RKIP) interactions with morphine and morphine-glucuronides determined by noncovalent mass spectrometry. Med Sci Monitor. 2009;15:178-187.

26. Zhang JH, Chung TD, Oldenburg KR. A Simple statistical parameter for use in evaluation and validation of high throughput screening assays. J Biomol Screen. 1999;4:67-73.

27. Wilhelm SM, Carter C, Tang L, et al. BAY 43-9006 exhibits broad spectrum oral antitumor activity and targets the RAF/MEK/ERK pathway and receptor tyrosine kinases involved in tumor progression and angiogenesis. Cancer Res. 2004;64:7099-7109.

28. Lackey K, Cory M, Davis R, et al. The discovery of potent cRafl kinase inhibitors. Bioorg Med Chem Lett. 2000;10:223-226.
29. Hall-Jackson CA, Eyers PA, Cohen P, et al. Paradoxical activation of Raf by a novel Raf inhibitor. Chem Biol. 1999;6:559-568.

30. Bakare O, Ashendel CL, Peng H, Zalkow LH, Burgess EM. Synthesis and MEK1 inhibitory activities of imido-substituted 2-chloro-1, 4-naphthoquinones. Bioorg Med Chem. 2003;11:3165-3170.

31. Favata MF, Horiuchi KY, Manos EJ, et al. Identification of a novel inhibitor of mitogen-activated protein kinase kinase. J Biol Chem. 1998;273:18623-18632.

32. Alessi DR, Cuenda A, Cohen P, Dudley DT, Saltiel AR. PD098059 is a specific inhibitor of the activation of mitogen-activated protein kinase kinase in vitro and in vivo. J Biol Chem. 1995;270:27489-27494.

33. Davies SP, Reddy H, Caivano M, Cohen P. Specificity and mechanism of action of some commonly used protein kinase inhibitors. Biochem J. 2000;351:95-105.

34. Ohori M, Kinoshita T, Okubo M, et al. Identification of a selective ERK inhibitor and structural determination of the inhibitor-ERK2 complex. Biochem Biophys Res Commun. 2005;336:357-363.

35. McDonald OB, Chen WJ, Ellis B, et al. A scintillation proximity assay for the Raf/MEK/ERK kinase cascade: high-throughput screening and identification of selective enzyme inhibitors. Anal Biochem. 1999;268:318-329.

36. Keller ET. Metastasis suppressor genes: a role for Raf Kinase Inhibitor Protein (RKIP) Anti-Cancer Drugs. 2004;15:663-669.

37. Chatterjee D, Bai Y, Wang Z, et al. RKIP sensitizes prostate and breast cancer cells to drug-induced apoptosis. J Biol Chem. 2004;279: $17515-17523$

38. Jazirehi AR, Bonavida B. Cellular and molecular signal transduction pathways modulated by rituximab (rituxan, anti-CD20 mAb) in non-Hodgkin's lymphoma: implications in chemosensitization and therapeutic intervention. Oncogene. 2005;24:2121-2143.

39. Zeng L, Imamoto A, Rosner MR. Raf kinase inhibitory protein (RKIP): a physiological regulator and future therapeutic target. Expert Opin Ther Targets. 2008;12:1275-1287.

40. Jia Y, Quinn CM, Talanian RV. Designing in vitro assays for drug discovery: a study with the human MAP3 kinase COT. Expert Opin Drug Discov. 2007;2:909-915.

41. Jia Y, Quinn CM, Clabbers A, et al. Comparative analysis of various in vitro COT kinase assay formats and their applications in inhibitor identification and characterization. Anal Biochem. 2006;350:268-276.
International Journal of High Throughput Screening

\section{Publish your work in this journal}

International Journal of High Throughput Screening is an international, peer-reviewed, open access journal publishing original research, reports, editorials, reviews and commentaries dedicated to all aspects of high throughput screening, especially related to drug discovery and associated areas of biology and chemistry. The manuscript management sys-

\section{Dovepress}

tem is completely online and includes a very quick and fair peer-review system. Visit http://www.dovepress.com/testimonials.php to read real quotes from published authors. 